HECKTHEUER, Pedro Abib; CASTRO, Raimundo Viana de; HECKTHEUER, Fabio Rychecki. Os impactos da judicialização da saúde no estado de Rondônia no período de 2010 a 2015 e a previsão de gastos para o biênio 2016-2017. Revista Eletrônica Direito e Política, Programa de Pós-Graduação Stricto Sensu em Ciência Jurídica da UNIVALI, Itajaí, v.13, n.2, $2^{\circ}$ quadrimestre de 2018. Disponível em: www.univali.br/direitoepolitica - ISSN 1980-7791

\title{
OS IMPACTOS DA JUDICIALIZAÇÃO DA SAÚDE NO ESTADO DE RONDÔNIA NO PERÍODO DE 2010 A 2015 E A PREVISÃO DE GASTOS PARA O BIÊNIO 2016-2017
}

\author{
THE IMPACTS OF HEALTH JUDICIALIZATION IN THE STATE OF RONDÔNIA IN THE PERIOD \\ 2010 TO 2015 AND THE EXPECTED EXPENDITURE FOR THE 2016-2017 BIENNIUM
}

\author{
Pedro Abib Hecktheuer ${ }^{1}$ \\ Raimundo Viana de Castro² \\ Fabio Rychecki Hecktheuer ${ }^{3}$
}

\begin{abstract}
SUMÁRIO: Introdução; 20 direito à saúde na Constituição de 1988 como um Direito Social; 3 A judicialização da saúde como consectário da jurisdição constitucional em seu aspecto direto de aplicação in concreto; 3.1 Judicialização da saúde: da controvérsia doutrinária à possibilidade de tutela judicial do mínimo existencial; 3.2 Judicialização da saúde: os tribunais brasileiros como "ordenadores de despesa"; 4 Judicialização da saúde em Rondônia: modus operandi do cumprimento das decisões judiciais no âmbito da administração pública estadual; 5 Os custos da judicialização da saúde em Rondônia no sexênio 2010-2015 e a sua baixa representatividade nas despesas do setor; 6 Sequestros do dinheiro público para o cumprimento de decisões judiciais: o lado obscuro dos gastos com saúde em Rondônia; 7 Judicialiação da saúde em Rondônia: previsão de custos para o biênio 2016-2017 através da análise de regressão; Considerações Finais; Referência das fontes citadas.
\end{abstract}

\section{RESUMO}

A partir da promulgação da Constituição Federal em 1988, constata-se no Brasil um aumento do número de decisões judiciais garantidoras do acesso à saúde. Os juízes tendem a desconsiderar o impacto orçamentário de suas decisões, admitindo que qualquer dos entes federativos pode figurar no polo passivo da demanda judicial. Esta pesquisa destina-se ao estudo da judicialização da saúde, concentrando-se, sobretudo, no impacto que essas decisões causaram no orçamento do Estado de Rondônia, no período de 2010 a 2015, através da comparação entre os valores previstos e os valores empenhados para o cumprimento dessas ordens judiciais, a partir de dados obtidos junto à Secretaria Estadual de Saúde e à Gerência de Contas do Tesouro Estadual, além de realizar a previsão dos gastos com a judicialização da saúde em Rondônia para o biênio 2016-2017, através da análise de regressão linear. Conforme estimativa obtida no presente trabalho, o custo da judicialização da saúde nesse período supera em $19,46 \%$ o valor previsto para esse tipo de despesa. No entanto, esse custo representa apenas $1,17 \%$ do gasto do governo estadual com todo o setor de saúde, correspondendo a um valor per capita médio de $\mathrm{R} \$ 5,34$. Bem

\footnotetext{
${ }^{1}$ Professor de Direito Constitucional e Coordenador do Curso de Direito da Faculdade Católica de Rondônia (FCR). Graduado em Direito pela Faculdade Palotina de Santa Maria, Rio Grande do Sul (FAPAS). Mestre em Direito Econômico e Socioambiental pela Pontifícia Universidade Católica do Paraná (PUCPR). Bolsista junto à Fundação Rondônia de Amparo ao Desenvolvimento das Ações científicas e tecnológicas e à Pesquisa do Estado de Rondônia - FAPERO/CAPES. Email: pedro@fcr.edu.br.

2 É formado em Filosofia pelo Seminário Maior João XXIII. Graduação em Matemática pela Universidade Federal de Rondônia (UNIR). Pós-Graduado em Educação Matemática pela Universidade Federal de Rondônia (UNIR). Bacharel em Direito pela Faculdade Católica de Rondônia (FCR). Pós-graduado em Direito Constitucional pela Estácio de Sá; Advogado. E-mail: rviana489@gmail.com.

${ }^{3}$ Professor dos Cursos de Direito e Filosofia da Faculdade Católica de Rondônia (FCR). Professor do Programa de Pós-Graduação em Ciência Política da Universidade Federal do Rio Grande do Sul (UFRGS). Graduado em Filosofia pela Universidade Católica de Pelotas (UCPEL). Mestre em Filosofia pela Pontifícia Universidade Católica do Rio Grande do Sul (PUCRS). Doutor em Desarrollo Psicológico y Aprendizaje Escolar pela Universidad Autonoma de Madrid (UAM). Pós-doutorado em Psicologia da Aprendizagem pela Universidad Autonoma de Madrid (UAM). Reitor da Faculdade Católica de Rondônia. Email: fabioheck@fcr.edu.br.
} 
HECKTHEUER, Pedro Abib; CASTRO, Raimundo Viana de; HECKTHEUER, Fabio Rychecki. Os impactos da judicialização da saúde no estado de Rondônia no período de 2010 a 2015 e a previsão de gastos para o biênio 2016-2017. Revista Eletrônica Direito e Política, Programa de Pós-Graduação Stricto Sensu em Ciência Jurídica da UNIVALI, Itajaí, v.13, n.2, $2^{\circ}$ quadrimestre de 2018. Disponível em: www.univali.br/direitoepolitica - ISSN 1980-7791

como foi desenvolvido um modelo matemático para servir como ferramenta para previsão de gastos, aferindo-se um decréscimo para os anos de 2016 e 2017, sendo que em relação a 2015 , é de $13,71 \%$ e $21,5 \%$, respectivamente, para que se possa, em uma futura pesquisa verificar a fidedignidade do modelo.

Palavras-chave: Impacto orçamentário; Estado de Rondônia; Judicialização da saúde; Valores previstos; Valores empenhados.

\section{ABSTRACT}

As of the promulgation of the Federal Constitution in 1988, it is verified in Brazil, Increase in the number of judicial decisions guaranteeing access to health. Judges tend to disregard the budgetary impact of their decisions, Assuming that any of the federative entities can appear in the passive pole of the judicial claim. This research is intended for a health judicialization study, focusing, above all, in the impact that those decisions caused in the budget of the State of Rondônia, in the period from 2010 to 2015, through the index between the expected values and the committed values for compliance of thouse court orders, based on data obtained from the State Department of Health and the State Treasury Accounts Management, in addition to making a forecast of expenditures with the health judicilization in Rondônia for the biennium 2016-2017, for Linear regression analysis. According to the estimate obtained in this study, the cost of health judicialization in this period was increased in $19.46 \%$ from the predicted value for this type of expenditure. However, this cost represents only $1.17 \%$ of the state government's expenditure with the entire health sector, corresponding to an average per capita value of $R \$ 5.34$. As well as, a mathematical model was developed to serve as a measure of expenditure disclosure, that found a decrease for the years 2016 and 2017 in relation to 2015, that is $13.71 \%$ and $21.5 \%$, respectively.

Keywords: Budgetary impact; State of Rondônia; Judicialization of health; Expected values; Committed values.

\section{INTRODUÇÃO}

O direito à saúde está previsto no artigo $6^{\circ}$ da Constituição da República Federativa do Brasil de 1988 e tem sua maior concretização em nível normativo-constitucional no artigo 1964, que o consagra como dever do Estado promover, por meio de políticas sociais e econômicas, o acesso universal e igualitário à saúde.

De acordo com Sarlet ${ }^{5}$, tal direito é uma pré-condição da dignidade da pessoa humana, um verdadeiro direito a ter direitos, já que é vinculado ao direito à vida, encontrando-se umbilicalmente atrelado à proteção da integridade física (corporal e psíquica) do ser humano.

Por se tratar de um direito social de cunho prestacional, a efetivação do direito à saúde encontra-se condicionada à realização de políticas públicas, isto é, depende de um conjunto de ações, programas e atividades desenvolvidas pelo Estado, o que exige necessariamente a aplicação de recursos públicos. Esses recursos, por sua vez, no Brasil, assim como em

\footnotetext{
${ }^{4}$ Art. 196. A saúde é direito de todos e dever do Estado, garantido mediante políticas sociais e econômicas que visem à redução do risco de doença e de outros agravos e ao acesso universal e igualitário às ações e serviços para sua promoção, proteção e recuperação (BRASIL. Constituição da República Federativa do Brasil. Brasília: Senado Federal, 1988).

${ }^{5}$ SARLET, Ingo Wolfgang; MARINONI, Luiz Guilherme; MITIDIERO, Daniel. Curso de Direito Constitucional. 6. ed., amp. São Paulo: Saraiva, 2017, p. 631.
} 
HECKTHEUER, Pedro Abib; CASTRO, Raimundo Viana de; HECKTHEUER, Fabio Rychecki. Os impactos da judicialização da saúde no estado de Rondônia no período de 2010 a 2015 e a previsão de gastos para o biênio 2016-2017. Revista Eletrônica Direito e Política, Programa de Pós-Graduação Stricto Sensu em Ciência Jurídica da UNIVALI, Itajaí, v.13, n.2, $2^{\circ}$ quadrimestre de 2018. Disponível em: www.univali.br/direitoepolitica - ISSN 1980-7791

qualquer país do mundo, são escassos, fato que leva o Estado a realizar as denominadas "escolhas trágicas", ${ }^{6}$ decidindo onde e como as verbas públicas serão aplicadas. Trata-se de escolhas políticas, que só podem ser feitas pelos órgãos previstos na Constituição e democraticamente legitimados pelo voto popular.

No Brasil, essa responsabilidade cabe ao Poder Legislativo, através de um mecanismo de planejamento intitulado Sistema Orçamentário, composto por três leis: Plano Plurianual (PPA), Lei de Diretrizes Orçamentárias (LDO) e Lei Orçamentária Anual (LOA), conforme dispõe o art. 165 da Constituição Federal. Ao Poder Executivo, por sua vez, incumbe realizar os gastos e implementar os objetivos de curto e médio prazo, na forma e nos limites previstos nos respectivos documentos orçamentários. ${ }^{7}$

Todavia, nas últimas décadas, por intermédio da judicialização das políticas públicas, principalmente no âmbito do direito à saúde, tem-se assistido, no Estado brasileiro, a uma substituição do Poder Legislativo pelo Poder Judiciário. Esse fenômeno, segundo Scaff ${ }^{8}$, tem transformado o que deveria ser "discricionariedade legislativa" em "discricionariedade judicial", pois através dele tem o Poder Judiciário realizado a transferência de recursos de serviços que deveriam atender a todos em condições de igualdade para garantir a integralidade a apenas alguns.

No Estado de Rondônia, não tem sido diferente. Diariamente, decisões judiciais de todas as instâncias impõem ao Poder Executivo o custeio de tratamentos médicos, inclusive em outras unidades da Federação, a realização de consultas médicas, exames e cirurgias, a entrega de medicamentos, alimentação especial e insumos terapêuticos, o transporte de pacientes em UTI's aéreas, a internação compulsória de dependentes químicos, entre outras obrigações, sem levar em consideração os recursos destinados à implementação da saúde no orçamento estadual.

Essas decisões judiciais, decorrentes da aplicação direta da Constituição, à margem do que determina a lei e das regulamentações administrativas - meios próprios para a criação e implementação de políticas públicas, respectivamente -, são dotadas de efeitos imediatos, obrigando o Estado a providenciar os produtos ou serviços demandados a preço de mercado,

\footnotetext{
${ }^{6}$ Conceito originalmente desenvolvido por Calabresi e Bobit (1978). Significa que, na execução de políticas públicas, como os recursos são limitados, cabe ao poder legitimamente constituído a escolha das ações que serão realizadas, o que, por vezes, pode ser trágico, já que alguns dos direitos não serão atendidos (BOBBITT, Philip; CALABRESI, Guido. Tragic Choices - The conflicts society confronts in the allocation of tragically scarcere sources. New Yorque: WW. Norton \& Company, 1978).

7 Os objetivos de longo prazo estão previstos na Constituição.

${ }^{8}$ SCAFF, Fernando Facury. Direito à saúde e os Tribunais. In: NUNES, Antônio José Avelãs; SCAFF, Fernando Facury. Os Tribunais e o Direito à Saúde. Porto Alegre: Livraria do Advogado, 2011, p. 107-110.
} 
HECKTHEUER, Pedro Abib; CASTRO, Raimundo Viana de; HECKTHEUER, Fabio Rychecki. Os impactos da judicialização da saúde no estado de Rondônia no período de 2010 a 2015 e a previsão de gastos para o biênio 2016-2017. Revista Eletrônica Direito e Política, Programa de Pós-Graduação Stricto Sensu em Ciência Jurídica da UNIVALI, Itajaí, v.13, n.2, $2^{\circ}$ quadrimestre de 2018. Disponível em: www.univali.br/direitoepolitica - ISSN 1980-7791

já que não há prazo suficiente para realizar o procedimento licitatório adequado, o que gera um aumento de custos para os cofres públicos.

O não cumprimento dessas decisões tem como consequência imediata o bloqueio de dinheiro público disponível nas contas do Estado, através de ordem judicial, com a imposição de multas, em caso de descumprimento, acarretando ao governo grande dificuldade de planejamento de gestão da saúde, com poucas alternativas de solução.

A medida adotada pelo Estado de Rondônia para resolver esse problema foi destinar em sua Lei Orçamentária Anual um valor para amparar essas despesas, conforme será visto adiante. Trata-se de um fundo financeiro para cobrir tais gastos. No entanto, como o planejamento financeiro é feito por estimativa da realização desse tipo de despesas de um ano para outro, não se sabe exatamente se esse fundo tem suportado esses gastos ou se o Executivo estadual tem tido a necessidade de remanejar o seu orçamento ou solicitar a suplementação de verbas para atender essas despesas.

O impacto da judicialização da saúde, em termos de gastos públicos, é conhecido em alguns estados e até em alguns municípios ${ }^{9,10,11}$, mas em relação ao Estado de Rondônia, pouca ou nenhuma informação se encontra disponível. Também não se conhece como essas medidas são cumpridas e as consequências que isso acarreta à Administração Pública estadual.

Dessa forma, estudar como a judicialização da saúde afeta o referido Estado, verificando, principalmente, se os valores inicialmente destinados aos gastos impostos por essas decisões são suficientes ou não, assim como, o modus operandi do cumprimento dessas decisões na esfera administrativa, é importante porque o Judiciário, ao desconsiderar as políticas públicas traçadas para o setor, pode prejudicar o planejamento e a gestão da saúde por esse Ente Federado. Além disso, os gastos tendem a superar os valores previstos no orçamento, haja vista o crescimento vertiginoso desse fenômeno no país ${ }^{12,13,14}$.

\footnotetext{
${ }^{9}$ ADVOCACIA-GERAL DA UNIÃO. Ministério da Saúde. Intervenção Judicial na saúde pública: panorama no âmbito da Justiça Federal e apontamentos na seara das justiças estaduais. Brasília, 2012.

${ }^{10}$ HACHEM, Daniel Wunder. A noção constitucional de desenvolvimento para além do viés econômico: reflexos sobre algumas tendências do Direito Público brasileiro. A\&C - Revista de Direito Administrativo \& Constitucional, Belo Horizonte, ano 13, n. 53, p. 133-168, jul./set. 2013.

${ }^{11}$ WANG, Daniel Wei L. et al. Os impactos da judicialização da saúde no município de São Paulo: gasto público e organização federativa. Rev. Adm. Pública. Vol. 48, n. 5, p. 1191-1206, set/out. 2014.

12 ADVOCACIA-GERAL DA UNIÃO. Ministério da Saúde. Intervenção Judicial na saúde pública: panorama no âmbito da Justiça Federal e apontamentos na seara das justiças estaduais. Brasília, 2012.

13 HACHEM, Daniel Wunder. A noção constitucional de desenvolvimento para além do viés econômico: reflexos sobre algumas tendências do Direito Público brasileiro. A\&C - Revista de Direito Administrativo \& Constitucional, Belo Horizonte, ano 13, n. 53, p. 133-168, jul./set. 2013.

${ }^{14}$ WANG, Daniel Wei L. et al. Os impactos da judicialização da saúde no município de São Paulo: gasto público e organização federativa. Rev. Adm. Pública. Vol. 48, n. 5, p. 1191-1206, set/out. 2014.
} 
HECKTHEUER, Pedro Abib; CASTRO, Raimundo Viana de; HECKTHEUER, Fabio Rychecki. Os impactos da judicialização da saúde no estado de Rondônia no período de 2010 a 2015 e a previsão de gastos para o biênio 2016-2017. Revista Eletrônica Direito e Política, Programa de Pós-Graduação Stricto Sensu em Ciência Jurídica da UNIVALI, Itajaí, v.13, n.2, $2^{\circ}$ quadrimestre de 2018. Disponível em: www.univali.br/direitoepolitica - ISSN 1980-7791

Diante desse cenário, este artigo pretende contribuir para o conhecimento nesse campo ao analisar o direito à saúde na Constituição de 1988, o entendimento predominante na doutrina e na jurisprudência sobre esse assunto, além de examinar como a judicialização da saúde se realiza no âmbito da Administração Pública estadual, assim como qual é a dimensão do impacto que esse fenômeno provoca nas finanças do Estado. Por último, a partir dos dados obtidos, utilizando a análise de regressão, este estudo se volta para a elaboração de um modelo matemático probabilístico capaz de realizar a previsão dos gastos do governo estadual com a judicialização da saúde nos próximos anos.

Para se alcançar os objetivos propostos, valeu-se primeiramente de pesquisa bibliográfica e documental, que consistiu na análise dos principais trabalhos publicados sobre o assunto e das principais jurisprudências do STJ e do STF, além de decisões do Poder Judiciário local, tanto em primeira quanto em segunda instância.

A forma como se dá o cumprimento das decisões judiciais garantidoras do acesso à saúde foi descrita a partir de informações obtidas junto ao Núcleo de Mandados Judiciais, setor da Secretaria Estadual de Saúde, após anuência do Secretário Estadual de Saúde, através de ofício enviado àquela Secretaria.

A estimativa dos gastos com a judicialização da saúde, por sua vez, foi realizada tomando como fontes de análise os dados obtidos junto ao Sistema da Administração Financeira de Estados e Municípios - SIAFEM - e planilhas contendo a relação anual de sequestros realizados nas contas bancárias do Estado, obtidas junto à Gerência de Contas do Tesouro - SEFIN. Desta forma, considera-se que foi possível analisar todo o gasto com a judicialização da saúde no período de 2010 a 2015, delimitação que se deu pelo fato de que não se obteve acesso aos dados completos da judicialização dos anos subsequentes (2016 e 2017) e deixaria lacunas na análise, aprofundamento que se fará em nova pesquisa.

Como, em relação aos seis primeiros anos, os sequestros não se encontravam identificados, fez-se necessária a realização de uma pesquisa empírica, no segundo semestre de 2016, junto ao sítio eletrônico do Tribunal de Justiça de Rondônia e do Tribunal Regional Federal da $1^{\text {a }}$ Região, o que permitiu mensurar quantos sequestros, para o cumprimento de decisões judiciais garantidoras do acesso à saúde, foram realizados nas contas do Estado, bem como através da soma desses valores, obteve-se o respectivo valor anual. Essa pesquisa, que incluiu os tratamentos fora do domicílio e os medicamentos e tratamentos oncológicos, gerou um rol de 3.320 decisões proferidas pelo Judiciário, determinando a apreensão do dinheiro público estadual para a compra de medicamentos, insumos terapêuticos, alimentação especial e a realização de procedimentos médicos. 
HECKTHEUER, Pedro Abib; CASTRO, Raimundo Viana de; HECKTHEUER, Fabio Rychecki. Os impactos da judicialização da saúde no estado de Rondônia no período de 2010 a 2015 e a previsão de gastos para o biênio 2016-2017. Revista Eletrônica Direito e Política, Programa de Pós-Graduação Stricto Sensu em Ciência Jurídica da UNIVALI, Itajaí, v.13, n.2, $2^{\circ}$ quadrimestre de 2018. Disponível em: www.univali.br/direitoepolitica - ISSN 1980-7791

Vale ressaltar que restaram 73 processos, correspondendo a um valor de aproximadamente R\$ 800 mil, que não foram localizados nos sítios eletrônicos dos tribunais citados acima, ou por já terem sido baixados, ou por algum equívoco em sua numeração, os quais foram desconsiderados por este estudo.

Como o valor total gasto com a judicialização corresponde ao valor destinado à Secretaria Estadual de Saúde, acrescido dos valores sequestrados nas contas correntes estaduais, para obtê-lo, utilizou-se a equação: valor total gasto anualmente $=$ valor previsto + valor sequestrado. Já para a obtenção do custo total do período foi realizada a soma dos respectivos valores gastos em cada ano.

Finalmente, o modelo matemático probabilístico foi obtido utilizando-se a técnica estatística denominada regressão linear, através da qual se procurou verificar a relação funcional entre a suplementação de verba que o governo realiza (aqui denominada de incremento) e o valor inicialmente previsto no orçamento, assim como também o ano em que essas despesas foram realizadas. Deve-se salientar que a previsão, em estatística, não pode abranger um período longo muito longo sob pena de perda da confiabilidade, por isso a delimitação do biênio 2016-2017 para aplicação do modelo, que será testado tão logo estejam disponíveis os dados para a realização da nova pesquisa empírica sobre o período.

Na prática, utilizou-se o programa XLSTAT (Adinsoft), software desenvolvido para análise estatística no Microsoft Excel. Na elaboração do modelo, considerou-se como incremento real a soma do valor obtido anualmente junto ao SIAFEM com o total sequestrado em cada ano. Assim, após uma transformação logarítmica realizada nos valores referentes ao ano, valor inicial e incremento, com a utilização da análise de regressão linear múltipla, obtevese um modelo capaz de realizar a previsão do incremento para o triênio 2016-2018, com um intervalo de confiança de $95 \%$, de modo que para encontrar o valor total gasto em cada um desses anos, somou-se o valor inicial com o incremento previsto.

Após os caminhos percorridos para obtenção dos dados, conforme supracitado, partiu-se para a análise e discussão. 
HECKTHEUER, Pedro Abib; CASTRO, Raimundo Viana de; HECKTHEUER, Fabio Rychecki. Os impactos da judicialização da saúde no estado de Rondônia no período de 2010 a 2015 e a previsão de gastos para o biênio 2016-2017. Revista Eletrônica Direito e Política, Programa de Pós-Graduação Stricto Sensu em Ciência Jurídica da UNIVALI, Itajaí, v.13, n.2, $2^{\circ}$ quadrimestre de 2018. Disponível em: www.univali.br/direitoepolitica - ISSN 1980-7791

\section{O DIREITO À SAÚDE NA CONSTITUIÇÃO DE 1988 COMO UM DIREITO SOCIAL}

A Constituição de 1988 é a primeira a consagrar expressamente o direito fundamental à saúde em seu texto ${ }^{15}$, sendo que as demais Cartas brasileiras apenas possuíam disposições esparsas sobre o assunto. Assim, além de reconhecê-lo como um direito social no art. 60, o constituinte originário, no art. 196, deu especial relevância aos seus aspectos curativo, preventivo e promocional.

A saúde curativa encontra-se contemplada no vocábulo "recuperação", de modo que diante de uma adversidade na área da saúde, o seu restabelecimento deve ocorrer por intermédio de um processo curativo. As expressões "redução de risco de doença" e "proteção" exteriorizam o aspecto preventivo da saúde, já que a atuação do poder público deve-se dar anteriormente à manifestação da doença. O vocábulo "promoção", por sua vez, traz à luz a importância de se buscar a qualidade de vida, o que, em outras palavras, evidencia o caráter promocional da saúde.

No art. 198, a Lei Fundamental de 1988 instituiu um sistema único de saúde (SUS), compreendendo as diversas ações e serviços públicos de saúde, a partir de uma rede regionalizada e hierarquizada, organizado sob as seguintes diretrizes: a) descentralização, com direção única em cada esfera de governo; b) atendimento integral, fixando prioridades de cunho preventivo, além dos serviços assistenciais e; c) participação da comunidade.

Já a Emenda Constitucional 29, de $2000^{16}$, incluiu no art. 198 do texto constitucional o § $2^{\circ}$, tornando obrigatória a aplicação de recursos mínimos em ações e serviços públicos de saúde, cujo descumprimento pode dar ensejo à intervenção federal ${ }^{17}$, conforme o art. 34, VII, " $e$ ", da Constituição.

O direito à saúde, desse modo, tanto por determinação expressa da Constituição, em seu art. $6^{\circ}$, quanto por exigir, para sua efetivação, um conjunto de ações positivas do Estado, configura-se como um direito social ou de segunda geração na classificação de Karel Vasak ${ }^{18}$.

\footnotetext{
15 MENDES, Gilmar Ferreira; BRANCO, Paulo Gustavo Gonet. Curso de Direito Constitucional. 7. ed., ver. e amp. São Paulo: Saraiva, 2012, p. 696.

${ }^{16}$ BRASIL. Emenda constitucional no 29 de 2000. Altera os arts. 34, 35, 156, 160, 167 e 198 da Constituição Federal e acrescenta artigo ao Ato das Disposições Constitucionais Transitórias, para assegurar os recursos mínimos para o financiamento das ações e serviços públicos de saúde. Brasília: Congresso Nacional, 13 de set. de 2000. 607.

${ }^{17}$ FERNANDES, Bernardo Gonçalves. Curso de Direito Constitucional. 7. ed., São Paulo: Juspodivm, 2015, p.

${ }^{18}$ Foi Karel Vasak, jurista tcheco-francês, que, a partir de 1979, no Instituto Internacional de Direitos Humanos, em Estrasburgo, com o objetivo de ilustrar o processo de mutação histórica dos direitos fundamentais, passou a difundir a ideia de que os direitos (humanos e fundamentais), poderia ser compreendida mediante a identificação de três gerações de direito (SARLET, Ingo Wolfgang; MARINONI, Luiz Guilherme; MITIDIERO, Daniel. Curso de Direito Constitucional. 6. ed., amp. São Paulo: Saraiva, 2017, p. 312).
} 
HECKTHEUER, Pedro Abib; CASTRO, Raimundo Viana de; HECKTHEUER, Fabio Rychecki. Os impactos da judicialização da saúde no estado de Rondônia no período de 2010 a 2015 e a previsão de gastos para o biênio 2016-2017. Revista Eletrônica Direito e Política, Programa de Pós-Graduação Stricto Sensu em Ciência Jurídica da UNIVALI, Itajaí, v.13, n.2, $2^{\circ}$ quadrimestre de 2018. Disponível em: www.univali.br/direitoepolitica - ISSN 1980-7791

Ponto controvertido na doutrina e jurisprudência, contudo, é saber se tal direito, dotado de eficácia imediata, segundo o $\S 1^{\circ}$ do art. $5^{\circ}$ da CF, e por representar a defesa de um direito individual no âmbito social, pode ser caracterizado como direito subjetivo e, como tal, passível de ser exigido judicialmente dos poderes públicos.

\section{A JUdicIALIZAÇÃo dA SAÚdE COMO CONSECTÁRIO DA JURISDIÇÃo CONSTITUCIONAL EM SEU ASPECTO DIRETO DE APLICAÇÃO IN CONCRETO}

A promulgação da Constituição de 1988 marcou, no Brasil, a superação do Estado legislativo de Direito pelo Estado constitucional de Direito, fenômeno que, na Europa continental, já vinha ocorrendo desde o final da Segunda Guerra Mundial ${ }^{19}$.

Passou-se, dessa forma, de um modelo de Estado em que vigorava a centralidade da lei e a supremacia do parlamento, para um modelo centralizado na Constituição, cuja supremacia repousa no Judiciário. No Estado constitucional de Direito, a Constituição deixou de ser apenas um documento político, cuja aplicação das normas dependia da atuação do legislador ou do administrador, para ser compreendida como norma jurídica, passando a disciplinar o modo de elaboração das leis e atos normativos, a estabelecer-Ihes certos limites quanto ao conteúdo, além de impor deveres de atuação ao Estado.

Nesse ambiente, começou a se destacar a denominada jurisdição constitucional, compreendendo, tanto a aplicação direta da Constituição por juízes e tribunais às situações nela previstas, quanto a aplicação indireta, através do controle de constitucionalidade ou da atribuição de interpretação conforme. No âmbito da aplicação direta das normas constitucionais por juízes e tribunais é que se encontra o fenômeno da judicialização ${ }^{20}$ de políticas públicas.

Através da judicialização da política, portanto, o Judiciário se sobrepõe aos demais poderes da República, passando a decidir sobre questões de índole tradicionalmente administrativa ou legislativa.

Vianna, Burgos e Salles ${ }^{21}$ observam que essa projeção do papel do juiz em quase todos os aspectos da vida social é um fenômeno contemporâneo da cultura democrática, que não deriva de pretensões de ativismo judiciário, mas de processos oriundos de múltiplas

\footnotetext{
19 NETO, Claudio Pereira de Souza; SARMENTO, Daniel. Direito Constitucional: Teoria, História e Métodos de Trabalho. 2a Ed. São Paulo: Saraiva, 2014.

20 Judicialização significa que questões relevantes do ponto de vista político, social ou moral estão sendo decididas, em caráter final, pelo Poder Judiciário. Trata-se, como intuitivo, de uma transferência de poder para as instituições judiciais, em detrimento das instâncias políticas tradicionais, que são o Legislativo e o Executivo (BARROSO, Luís Roberto. Curso de Direito Constitucional Contemporâneo: os conceitos fundamentais e a construção do novo modelo. São Paulo: 5. ed., Saraiva, 2015, p. 437).

21 VIANNA, Luiz Werneck et al. Dezessete anos de judicialização da política. Tempo Social, revista de sociologia da USP. Vol. 19 , n 2, p. 39-85, nov. 2007, p. 39.
} 
HECKTHEUER, Pedro Abib; CASTRO, Raimundo Viana de; HECKTHEUER, Fabio Rychecki. Os impactos da judicialização da saúde no estado de Rondônia no período de 2010 a 2015 e a previsão de gastos para o biênio 2016-2017. Revista Eletrônica Direito e Política, Programa de Pós-Graduação Stricto Sensu em Ciência Jurídica da UNIVALI, Itajaí, v.13, n.2, $2^{\circ}$ quadrimestre de 2018. Disponível em: www.univali.br/direitoepolitica - ISSN 1980-7791

instâncias e que resultam de várias transformações, as quais afetaram a sociedade ocidental, desde o segundo pós-guerra. Essas transformações incluíram, dentre outros acontecimentos, a própria guerra, com o Tribunal de Nuremberg; a promulgação de constituições contendo um núcleo dogmático, explicitando valores fundamentais; e a crise do Welfare State. Esse último teve como resposta a emergência do neoliberalismo, que com suas reformas retirou de cena escoras que asseguravam direitos sociais. Desse modo, sem Estado, sem fé, sem partidos e sindicatos, as expectativas de setores da sociedade deslizaram para o interior do Poder Judiciário, o muro das lamentações no mundo moderno.

No Brasil, uma das áreas mais propícias para a judicialização da política é a que incide sobre o direito à saúde, onde tal fenômeno se caracteriza pela interferência do Poder Judiciário nas políticas públicas, mediante determinações à Administração Pública para que custeie tratamentos dispendiosos, forneça medicamentos e outros insumos terapêuticos, realize o pagamento de cirurgias ou de tratamentos compulsórios de drogadição, etc., gerando um custo direto e imediato aos cofres públicos.

Essa interferência do Poder Judiciário nas políticas públicas de saúde, que, segundo Pepe et al 22 , "teve início na década de noventa, com pedidos de medicamentos antirretrovirais para o HIV/aids", atualmente tem gerado grandes preocupações, tanto nos gestores públicos e estudiosos do assunto, como em toda a sociedade. Dados do Ministério da Saúde ${ }^{23}$ indicam que a judicialização da saúde subiu 500\% entre 2010 e 2014, somando $R \$ 2,1$ bilhões nesse período, apenas na esfera federal. Naquele ano, o valor consumido foi de R\$139,6 milhões. Somente em 2014, o gasto chegou a R\$ 838,4 milhões. O Estado de São Paulo já gasta em média $R \$ 1$ bilhão por ano com ações judiciais, enquanto seu custo total para assistência farmacêutica em todo o SUS é de R\$ 600 milhões.

Essas decisões que implementam o direito à saúde diretamente da Lei Maior constituem uma espécie daquilo que Scaff ${ }^{24}$, transportando para o Brasil uma expressão muito utilizada na doutrina italiana, denominada de "sentenças aditivas", que são aquelas que implicam aumento de custo para o Erário, obrigando-o ao reconhecimento de um direito social não previsto originalmente no orçamento do poder público demandado, pois determinam o desembolso imediato por parte da Administração Pública, em favor de alguém ou a

\footnotetext{
22 PEPE et al. A judicialização da saúde e os novos desafios da gestão da assistência farmacêutica. Ciência \& Saúde Coletiva, Rio de Janeiro, v. 15, n. 5, 2010, p. 2406.

${ }^{23}$ INTERFARMA. Associação da Indústria Farmacêutica de Pesquisa. Judicialização da saúde na prática: fatos e dados da realidade brasileira. São Paulo, 2016. Disponível em: <http://www.interfarma.org.br/uploads/biblioteca/102-caderno-judicializacao-jul2016-site.pdf >. Acesso em: 08.082016.

${ }^{24}$ SCAFF, Fernando Facury. Sentenças aditivas, direitos sociais e reserva do possível. In: SARLET, Ingo Wolfgang; TIM, Luciano Benetti. Direitos Fundamentais: orçamento e reserva do possível. Porto Alegre: Livraria do Advogado, 2013, p. 133-134.
} 
HECKTHEUER, Pedro Abib; CASTRO, Raimundo Viana de; HECKTHEUER, Fabio Rychecki. Os impactos da judicialização da saúde no estado de Rondônia no período de 2010 a 2015 e a previsão de gastos para o biênio 2016-2017. Revista Eletrônica Direito e Política, Programa de Pós-Graduação Stricto Sensu em Ciência Jurídica da UNIVALI, Itajaí, v.13, n.2, $2^{\circ}$ quadrimestre de 2018. Disponível em: www.univali.br/direitoepolitica - ISSN 1980-7791

realização imediata de um determinado procedimento médico, compra de medicamentos ou serviços, gerando grande desconforto ao sistema orçamentário dos entes públicos, deixando-Ihes poucas alternativas a adotar.

Para compreender de que forma se posiciona a doutrina diante desse fenômeno, necessário se faz que aprofundemos a discussão bibliográfica, conforme se verá a seguir.

\subsection{JUDICIALIZAÇÃO DA SAÚDE: DA CONTROVÉRSIA DOUTRINÁRIA À POSSIBILIDADE DE TUTELA JUDICIAL DO MÍNIMO EXISTENCIAL}

No que concerne à interferência do Poder Judiciário brasileiro nas políticas públicas de saúde, os doutrinadores nacionais têm-se dividido entre aqueles que consideram esse direito fundamental um direito subjetivo público, portanto, passível de concretização por intermédio de decisões judiciais, e outros que Ihes negam essa condição.

Alinhado com o primeiro entendimento, destacam-se Sarlet e Figueiredo ${ }^{25}$, para quem o direito social à saúde, assim consagrado no art. $6^{\circ}$ da Constituição de 1988, normatizado pelo seu art. 196, autoriza a propositura de demandas individuais em face da Administração Pública, desde que se adote como critério o princípio da proporcionalidade em sua dupla dimensão de proibição de excesso e de insuficiência, observando-se, assim, os critérios parciais da adequação (aptidão do meio à consecução da finalidade almejada), necessidade (menor sacrifício do direito restringido) e da proporcionalidade em sentido estrito (avaliação da equação custo-benefício). Isso, porém, segundo eles, não afasta a necessidade de se reconhecer um direito subjetivo em casos de urgência.

Para esses autores, o fato de o direito à saúde ser um direito social, não lhe retira a condição de ser, primeiramente direito fundamental de cada pessoa, ainda mais que a dignidade é sempre da pessoa concretamente considerada. Em sentido contrário ao posicionamento de Sarlet e Figueiredo, afirma Scaff ${ }^{26}$ que:

[...] o direito à saúde não consagra direitos individuais, mas direitos difusos, que devem ser obtidos sob a forma da justiça distributiva, mais facilmente alcançável junto ao Poder Legislativo (na formulação de políticas públicas) e ao Poder Executivo (na implementação de políticas públicas) do que pela via judicial individual.

Para o referido autor, admitir a efetivação do direito à saúde mediante decisões judiciais seria transferir a fila do SUS para o Poder Judiciário, com o agravante de que tal Poder distribui justiça apenas a quem Ihe pede, geralmente os que têm maior poder aquisitivo e,

25 SARLET, Ingo Wolfgang; FIGUEIREDO, Mariana Filchtiner. Reserva do possível, mínimo existencial e direito à saúde: algumas aproximações. In: SARLET, Ingo Wolfgang; TIM, Luciano Benetti. Direitos Fundamentais: orçamento e reserva do possível. Porto Alegre: Livraria do Advogado, 2013, p. 33.

${ }^{26}$ SCAFF, Fernando Facury. Direito à saúde e os Tribunais. In: NUNES, Antônio José Avelãs; SCAFF, Fernando Facury. Os Tribunais e o Direito à Saúde. Porto Alegre: Livraria do Advogado, 2011, p. 132. 
HECKTHEUER, Pedro Abib; CASTRO, Raimundo Viana de; HECKTHEUER, Fabio Rychecki. Os impactos da judicialização da saúde no estado de Rondônia no período de 2010 a 2015 e a previsão de gastos para o biênio 2016-2017. Revista Eletrônica Direito e Política, Programa de Pós-Graduação Stricto Sensu em Ciência Jurídica da UNIVALI, Itajaí, v.13, n.2, $2^{\circ}$ quadrimestre de 2018. Disponível em: www.univali.br/direitoepolitica - ISSN 1980-7791

por consequência, mais informados, em detrimento daqueles que realmente necessitam e que não dispõem de tais informações. Ao agir dessa forma, o Poder Judiciário estaria apostando que alguns não chegariam à justiça e que esses não lhes importam, que esses não devem ser levados em consideração.

Nessa mesma linha de intelecção, Mendes ${ }^{27}$ sustenta que há, na verdade, um direito subjetivo público, mas a políticas públicas, que promovam, protejam e recuperem a saúde e não um direito absoluto a todo e qualquer procedimento destinado à proteção, promoção e recuperação da saúde.

Aqueles que negam a possibilidade de tutela judicial ao direito à saúde, quase sempre o fazem com base na cláusula da reserva do possível. Essa cláusula, segundo Caliendo ${ }^{28}$, é entendida como limite ao poder do Estado de concretizar efetivamente direitos a prestações, tendo por origem a doutrina constitucionalista alemã da limitação de acesso ao ensino universitário. Nesse caso, a Corte Constitucional alemã entendeu existirem limitações fáticas para o atendimento de todas as demandas de acesso a um direito.

Essa teoria é sustentada pela ideia de que em toda ordem econômica os recursos são finitos, sendo necessário estabelecer critérios para sua alocação, com o escopo de satisfazer ao máximo os direitos sociais, o que só poderá ser feito mediante a criação e implementação de políticas públicas.

Por outro lado, há autores que limitam a reserva do possível à garantia do mínimo existencial, conjunto de prestações materiais indispensáveis para assegurar a cada pessoa uma vida condigna, no sentido de uma vida saudável. Nesse sentido, posiciona-se Barcellos ${ }^{29}$, para quem, somente depois de garantido o mínimo existencial é que se poderá dar início à tomada de decisão e escolha sobre quais valores e bens serão distribuídos e quais deverão ser sacrificados. Em relação ao mínimo existencial, não há escolha, o poder público deve garanti-lo.

Ao se compreender que os direitos fundamentais são "todos aqueles direitos subjetivos que correspondem universalmente a todos os seres humanos enquanto dotados de status de

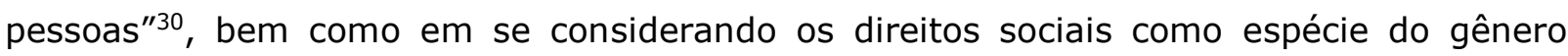

\footnotetext{
27 MENDES, Gilmar Ferreira; BRANCO, Paulo Gustavo Gonet. Curso de Direito Constitucional. 7. ed., ver. e amp. São Paulo: Saraiva, 2012, p. 697.

${ }^{28}$ CALIENDO, Paulo. Reserva do possível, direitos fundamentais e tributação. In: SARLET, Ingo Wolfgang; TIM, Luciano Benetti. Direitos Fundamentais: orçamento e reserva do possível. Porto Alegre: Livraria do Advogado, 2012, p. 180.

${ }^{29}$ BARCELLOS, Ana Paula de. A eficácia jurídica dos princípios constitucionais. Rio de Janeiro: Renovar, 2002, p. 245-246.
}

${ }^{30}$ FERRAJOLI, Luigi. Los Fundamentos de los Derechos Fundamentales. Madrid: Trotta, 2001, p. 19. 
HECKTHEUER, Pedro Abib; CASTRO, Raimundo Viana de; HECKTHEUER, Fabio Rychecki. Os impactos da judicialização da saúde no estado de Rondônia no período de 2010 a 2015 e a previsão de gastos para o biênio 2016-2017. Revista Eletrônica Direito e Política, Programa de Pós-Graduação Stricto Sensu em Ciência Jurídica da UNIVALI, Itajaí, v.13, n.2, $2^{\circ}$ quadrimestre de 2018. Disponível em: www.univali.br/direitoepolitica - ISSN 1980-7791

direitos fundamentais, seriam também estes considerados subjetivos ${ }^{31}$. Há divergência quanto a esta compreensão, e ela se encontra no ponto de que apenas seria subjetivo quando dirigido ao mínimo existencial ${ }^{32}$, de modo que os demais somente podem ser exigidos nos limites de sua possibilidade técnica e financeira, constituindo-se em normas programáticas que estabelecem o dever do administrador de buscar sempre alcançar a máxima eficácia possível.

Assim, sendo o direito à saúde um componente obrigatório do mínimo existencial, não resta dúvida de que, como tal, constitui-se em um direito subjetivo, podendo ser tutelado judicialmente, devendo, todavia, ser analisado em seu contexto fático, observando-se o princípio da proporcionalidade (adequação, necessidade e proporcionalidade em sentido estrito).

Compreendido o entendimento a respeito da eficácia e aplicabilidade dos direitos sociais, a partir do posicionamento de estudiosos do assunto, importante se faz que seja verificada a interpretação que tem sido dada pelo Judiciário brasileiro quanto à judicialização da saúde.

\subsection{JUDICIALIZAÇÃO DA SAÚDE: OS TRIBUNAIS BRASILEIROS COMO "ORDENADORES DE DESPESA"}

O entendimento do Poder Judiciário brasileiro quanto à judicialização da saúde, pode ser demonstrado através das decisões proferidas pelo Superior Tribunal de Justiça (STJ) e pelo Supremo Tribunal Federal (STF).

No que diz respeito ao Superior Tribunal de Justiça, em 2010, no Recurso em Mandado de Segurança no 24.197/PR ${ }^{33}$, a $1^{\text {a }}$ Turma decidiu por condenar o ente público ao fornecimento gratuito de medicamentos para o tratamento de hepatite $C$, em acórdão, arguindo que:

1. A ordem constitucional vigente, em seu art. 196, consagra o direito à saúde como dever do Estado, que deverá, por meio de políticas sociais e econômicas, propiciar aos necessitados não "qualquer tratamento", mas o tratamento mais adequado e eficaz, capaz de ofertar ao enfermo maior dignidade e menor sofrimento.

2. Sobreleva notar, ainda, que hoje é patente a ideia de que a Constituição não é ornamental, não se resume a um museu de

\footnotetext{
${ }^{31}$ GLOECKNER, Joseane Ledebrum. A reserva do possível como limite à efetividade do direito fundamental à saúde. A\&C-Revista de Direito Administrativo \& Constitucional, v. 13, n. 51, p. 233-250, 2013, p. 240.

${ }^{32}$ CALIENDO, Paulo. Reserva do possível, direitos fundamentais e tributação. In: SARLET, Ingo Wolfgang; TIM, Luciano Benetti. Direitos Fundamentais: orçamento e reserva do possível. Porto Alegre: Livraria do Advogado, 2013 , p. 180 a 185.

${ }^{33}$ BRASIL. Superior Tribunal de Justiça. Recurso Ordinário em Mandado de Segurança no 24.197, do Tribunal de Justiça do, Brasília, DF, 4 de maio de 2010. Disponível em: http://stj.jusbrasil.com.br/jurisprudencia/16825941/recurso-ordinario-em-mandado-de-seguranca-rms-24197pr-2007-0112500-5/inteiro-teor-16825942. Acesso em: 28 out. 2015.
} 
HECKTHEUER, Pedro Abib; CASTRO, Raimundo Viana de; HECKTHEUER, Fabio Rychecki. Os impactos da judicialização da saúde no estado de Rondônia no período de 2010 a 2015 e a previsão de gastos para o biênio 2016-2017. Revista Eletrônica Direito e Política, Programa de Pós-Graduação Stricto Sensu em Ciência Jurídica da UNIVALI, Itajaí, v.13, n.2, $2^{\circ}$ quadrimestre de 2018. Disponível em: www.univali.br/direitoepolitica - ISSN 1980-7791

\section{princípios, não é meramente um ideário; reclama efetividade real de suas normas $[\ldots]^{34}$. Grifos nossos.}

O Superior Tribunal de Justiça, portanto, posicionou-se ao lado da efetivação do direito à saúde, através da aplicação direta das normas constitucionais, à revelia da formulação e execução de políticas sociais e econômicas, sob o argumento de que a Constituição necessita ter força normativa, não se resumindo a um museu de princípios.

A posição isolada daquele tribunal revelou-se no voto do Ministro Teori Zavascki, no mesmo julgamento ${ }^{35}$, o qual destacou que "[...] O que a Constituição assegura, em seu art. 196, é direito à saúde (e correspondente dever do Estado) garantido mediante políticas sociais e econômicas [...]", a serem estabelecidas e promovidas pelos poderes Legislativo e Executivo, cabendo ao Judiciário apenas o controle da juridicidade e do cumprimento dessas decisões políticas, baseando-se na garantia à prestação do direito ao mínimo existencial.

Os julgamentos do STF, por outro lado, devem ser analisados considerando-se dois momentos distintos: antes e depois da Audiência Pública para debater a judicialização do direito à saúde, realizada nos dias 27, 28 e 29 de abril, e em 4, 6 e 7 de maio de 2009 .

Antes dessa Audiência Pública, prevalecia no STF entendimento semelhante ao do STJ, com destaque para a Petição no $1.246 / S^{36}$, na qual um menor de idade, portador de uma doença rara denominada Distrofia Muscular de Duchene, alegando existir um tratamento nos Estados Unidos, com base no art. 196 da Constituição pleiteou que Ihe fosse concedido diretamente por aquele Estado o valor de US\$ 63 mil para custeio do tratamento, o que foi concedido em primeira instância. O Estado de Santa Catarina recorreu ao Tribunal de Justiça. A questão chegou ao STF, momento em que o Estado-Membro postulou à Corte a suspensão da tutela antecipada, argumentando violação aos arts. 37, 100 e 167 da Constituição, por ter ocorrido ordem de pagamento sem base no orçamento, nem lei que o determinasse. Em despacho monocrático o Ministro Celso de Mello negou a suspensão, arguindo que:

Entre proteger a inviolabilidade do direito à vida, que se qualifica como direito subjetivo inalienável assegurado pela própria Constituição da República (art. 50, caput) ou fazer prevalecer, contra esta prerrogativa fundamental, um interesse financeiro e secundário do Estado, entendo - uma vez configurado este dilema - que as

\footnotetext{
${ }^{34}$ BRASIL. Superior Tribunal de Justiça. Recurso Ordinário em Mandado de Segurança no 24.197, do Tribunal de Justiça do, Brasília, DF, 4 de maio de 2010. Disponível em: http://stj.jusbrasil.com.br/jurisprudencia/16825941/recurso-ordinario-em-mandado-de-seguranca-rms-24197pr-2007-0112500-5/inteiro-teor-16825942. Acesso em: 28 out. 2015.
}

${ }^{35}$ BRASIL. Superior Tribunal de Justiça. Recurso Ordinário em Mandado de Segurança no 24.197, do Tribunal de Justiça do, Brasília, DF, 4 de maio de 2010. Disponível em: http://stj.jusbrasil.com.br/jurisprudencia/16825941/recurso-ordinario-em-mandado-de-seguranca-rms-24197pr-2007-0112500-5/inteiro-teor-16825942. Acesso em: 28 out. 2015.

${ }^{36}$ BRASIL. Supremo Tribunal Federal. Medida Cautelar na Petição n. 1246, Presidente Ministro Sepúlveda Pertence, decisão Proferida pelo Ministro Celso de Mello, julgado em 31.01.1997. DJ, 13.02. 1997. 
HECKTHEUER, Pedro Abib; CASTRO, Raimundo Viana de; HECKTHEUER, Fabio Rychecki. Os impactos da judicialização da saúde no estado de Rondônia no período de 2010 a 2015 e a previsão de gastos para o biênio 2016-2017. Revista Eletrônica Direito e Política, Programa de Pós-Graduação Stricto Sensu em Ciência Jurídica da UNIVALI, Itajaí, v.13, n.2, $2^{\circ}$ quadrimestre de 2018. Disponível em: www.univali.br/direitoepolitica - ISSN 1980-7791

razões de índole ético-jurídicas impõem ao julgador uma só e possível opção: o respeito indeclinável à vida. ${ }^{37}$.

Essas razões passaram a fundamentar as decisões daquela Corte, em matéria de saúde, sendo reproduzidas, a partir daí, em diversos outros julgados ${ }^{38}$.

Outra decisão do STF que se encontra entre as mais citadas nas questões relacionadas ao direito à saúde é a proferida no julgamento da Arguição de Descumprimento de Preceito Fundamental (ADPF) $45^{39}$ na qual o relator, Ministro Celso de Mello, firmou o entendimento de que quando os órgãos estatais competentes, por ação ou omissão, descumprirem seus encargos, comprometendo a eficácia e a integralidade de direitos individuais ou coletivos consagrados na Constituição Federal (ainda que normas programáticas), poderá tal incumbência ser atribuída ao Judiciário, já que o caráter programático das regras constitucionais não pode converter-se em promessa constitucional inconsequente. Também entendeu o ministro que, comprovada a inexistência de recursos financeiros, não poderá o Estado ser obrigado a concretizar os direitos de segunda geração. No entanto, a cláusula da reserva do possível não poderá ser alegada pelo Estado com a finalidade de exonerar-se do cumprimento do mínimo existencial.

Para Scaff ${ }^{40}$, "[...] esta proclamação in abstrato não possui valor nem de precedente jurisprudencial, nem de jurisprudência assente para o STF e os demais órgãos do Poder Judiciário brasileiro [...]". Trata-se, segundo ele, de bela proclamação sem nenhuma deliberação no caso concreto, não sendo sequer acórdão, mas um longo obter dictum sobre aplicabilidade das normas constitucionais, em especial sobre o direito à saúde, cuja única deliberação processual foi o julgamento da prejudicialidade da referida ADPF, em virtude da perda superveniente do seu objeto.

Após a realização da Audiência Pública de 2009, o STF criou balizas jurisprudenciais para análise dessas demandas, sendo o leading case desse paradigma a decisão proferida na STA-AgR $175 / \mathrm{CE}^{41}$, segundo a qual deve o Judiciário intervir para fazer cumprir as ações

37 BRASIL. Supremo Tribunal Federal. Medida Cautelar na Petição n. 1246, Presidente Ministro Sepúlveda Pertence, decisão Proferida pelo Ministro Celso de Mello, julgado em 31.01.1997. DJ, 13.02. 1997. 38"As decisões que citam esta passagem são: RE 267612, AI 570455, AgRg no RE 271286, RE 198265, RE
248304, AgRg no RE 273834 e RE 393175". (WANG, Daniel Wei Liang. Escassez de recursos, custos dos
direitos e reserva do possível na jurisprudência do STF. In: SARLET, Ingo Wolfgang; TIMM, Luciano Benetti
(Coord.). Direitos fundamentais: orçamento e "reserva do possível". 2. ed. Porto Alegre: Livraria do Advogado,
2010, p.354, nota n. ${ }^{\circ}$ 19).

${ }^{39}$ BRASIL. Supremo tribunal Federal. ADPF no 45. Rel. Min. Celso de Mello, julgado em 29.04.2004. DJ, 04.05 2004.

${ }^{40}$ SCAFF, Fernando Facury. Direito à saúde e os Tribunais. In: NUNES, Antônio José Avelãs; SCAFF, Fernando Facury. Os Tribunais e o Direito à Saúde. Porto Alegre: Livraria do Advogado, 2011, p. 119.

${ }^{41}$ BRASIL. Superior Tribunal de Justiça. Recurso Ordinário em Mandado de Segurança no 24.197, do Tribunal de Justiça do, Brasília, DF, 4 de maio de 2010. Disponível em: 
HECKTHEUER, Pedro Abib; CASTRO, Raimundo Viana de; HECKTHEUER, Fabio Rychecki. Os impactos da judicialização da saúde no estado de Rondônia no período de 2010 a 2015 e a previsão de gastos para o biênio 2016-2017. Revista Eletrônica Direito e Política, Programa de Pós-Graduação Stricto Sensu em Ciência Jurídica da UNIVALI, Itajaí, v.13, n.2, $2^{\circ}$ quadrimestre de 2018. Disponível em: www.univali.br/direitoepolitica - ISSN 1980-7791

previstas nas políticas do SUS, quando tais ações não estiverem sendo cumpridas pela Administração. Assim, a interferência do Judiciário consistirá em tornar a legislação efetiva. Se a ação de saúde pleiteada, não estiver entre as políticas estabelecidas pelo SUS, devese verificar se ela decorre de uma omissão legislativa ou administrativa, ou se de uma decisão administrativa que não a concedeu. No primeiro caso, deve ser concedido o tratamento estabelecido pelo SUS, permitindo-se a interferência do Judiciário, em se comprovando que o tratamento fornecido não é adequado para aquele paciente. Já na segunda hipótese, deve-se verificar se a negativa por parte da administração foi em virtude de o SUS fornecer tratamento alternativo, caso em que este deve ser privilegiado, ou se o foi porque o SUS não dispõe de tratamento para esta patologia, situação em que, sendo um tratamento experimental, caracterizar-se-á como pesquisa médica, não sendo possível ao Poder Judiciário deferir tais pedidos, ou por ser um novo tratamento ainda não testado pelo SUS, mas disponível na rede privada. Nesse último caso, deve o Judiciário intervir para que o SUS dispense aos seus pacientes o mesmo tratamento disponível na rede privada, mas desde que haja instrução probatória, inviabilizando-se o uso de liminares.

No Estado de Rondônia, essas balizas traçadas pelo STF, em regra, não têm sido observadas pelo Poder Judiciário.

As decisões do Tribunal de Justiça do Estado seguem o entendimento de que a responsabilidade para implementar o direito à saúde é solidária entre União, Estados e Municípios, podendo qualquer deles figurar no polo passivo da demanda, independentemente da verificação do cumprimento das políticas traçadas pelo Executivo, com fundamento nos arts. $6^{\circ}$ e 196, da Constituição Federal. Nesse sentido, tem-se o julgamento da apelação no. 0010662-75.2012.822.0014 ${ }^{42}$ e do agravo de no. 002135589.2014.822.000143.

Na primeira instância estadual, verifica-se um grande número de decisões que implementam o direito à saúde, sem observar se a ação pretendida se encontra entre as políticas do SUS, nem se, em se tratando de inexistência de tratamento estabelecido por este sistema, é previsto tratamento alternativo ou não, assim como não se considera o fato de o direito pleiteado consistir em tratamento experimental.

http://stj.jusbrasil.com.br/jurisprudencia/16825941/recurso-ordinario-em-mandado-de-seguranca-rms-24197pr-2007-0112500-5/inteiro-teor-16825942. Acesso em: 28 out. 2015.

42 RONDÔNIA. Tribunal de Justiça do Estado de Rondônia. APL 00106627520128220014 RO $0010662-$ 75.2012.822.0014. Rel. Des. Roosevelt Queiroz Costa, 2a Câmara Especial, julgado em 13.05.2014. DOE, 28.05.2014.

43 RONDÔNIA. Tribunal de Justiça do Estado de Rondônia. AGV 00213558920148220001 RO 0021355 89.2014.822.0001, Rel. Des. Renato Mimessi, julgado em 04.10.2016. DOE, 07.10.2016. 
HECKTHEUER, Pedro Abib; CASTRO, Raimundo Viana de; HECKTHEUER, Fabio Rychecki. Os impactos da judicialização da saúde no estado de Rondônia no período de 2010 a 2015 e a previsão de gastos para o biênio 2016-2017. Revista Eletrônica Direito e Política, Programa de Pós-Graduação Stricto Sensu em Ciência Jurídica da UNIVALI, Itajaí, v.13, n.2, $2^{\circ}$ quadrimestre de 2018. Disponível em: www.univali.br/direitoepolitica - ISSN 1980-7791

Um número expressivo das sentenças e das decisões que concedem antecipação de tutela, em algumas comarcas, segue um "modelo predeterminado", no qual o juiz apenas insere o nome do autor e do medicamento ou procedimento, além da data, mantendo-se intacto o fundamento.

Exceção a essa "regra", observa-se na Ação Ordinária 0006109-69.2013.8.22.0007, da $1^{\text {a }}$ Vara Cível da Comarca de Cacoal ${ }^{44}$, na qual o autor, portador de adrenoleucodistrofia, doença rara e degenerativa, pleiteou que the fosse concedido, por aquele município tratamento multidisciplinar domiciliar, cujos custos superariam $\mathrm{R} \$ 50.000,00$ mensais.

Na decisão que concedeu a tutela, o juízo de primeiro grau fez uma análise aprofundada do caso, considerando que as questões que permeiam a judicialização da saúde, v.g., a responsabilidade solidária dos Entes Públicos, a reserva do possível, assim como a responsabilidade de cada cidadão, de prover sua própria saúde, não se lhe aplicavam da mesma forma que nos demais. In verbis:

Não se trata de um exame de raio $x$, um colírio ou remédio para controle do colesterol, dentre outros. Não se cuida de doença comum, o que poderia redundar num alto volume de pedidos assemelhados, tal qual o lixo na cidade do Rio de Janeiro, em infeliz comparação feita pelo Estado em sua contestação ${ }^{45}$.

Entendeu o Judiciário que a situação foge à circunstância do "homem médio", restando ao autor pleitear ajuda ao ente público, garantidor legal de sua vida e saúde, e que os argumentos da falta de recursos dos réus (o município denunciou o Estado à lide) não se sustentavam, pois a tributação praticada (uma das mais altas em todo o mundo) afastaria qualquer alegação de falta de receita.

Na sentença, restou reconhecido que "[...] soa infundada e beira a covardia a pretensão dos réus de imputar ao autor a responsabilidade pela situação da saúde sob gestão de ambos os entes", e que diante de situação tão peculiar é a lei que deve se amoldar ao caso concreto e não o contrário. Nestes termos:

[...] ao policial é determinado que, ao encontrar três pessoas em uma motoneta apreenda o veículo e multe o proprietário e piloto. Mesmo que seja um pai, mãe e bebê, em Município totalmente desprovido de transporte público.

Por que, então, quando a obrigação é do ente público, é pleiteada a flexibilização das Leis? Ao contrário, a Lei não deve ser cumprida com

\footnotetext{
${ }^{44}$ RONDÔNIA. Tribunal de Justiça do Estado de Rondônia. 1 a Vara Cível de Cacoal. Ação Ordinária 000610969.2013.8.22.0007. Juíza de Direito Emy Karla Yamamoto Roque, julgado em 29.08.2014. DJ, 03.09.2014.

${ }^{45}$ RONDÔNIA. Tribunal de Justiça do Estado de Rondônia. $1^{a}$ Vara Cível de Cacoal. Ação Ordinária 000610969.2013.8.22.0007. Juíza de Direito Emy Karla Yamamoto Roque, julgado em 29.08.2014. DJ, 03.09.2014.
} 
HECKTHEUER, Pedro Abib; CASTRO, Raimundo Viana de; HECKTHEUER, Fabio Rychecki. Os impactos da judicialização da saúde no estado de Rondônia no período de 2010 a 2015 e a previsão de gastos para o biênio 2016-2017. Revista Eletrônica Direito e Política, Programa de Pós-Graduação Stricto Sensu em Ciência Jurídica da UNIVALI, Itajaí, v.13, n.2, $2^{\circ}$ quadrimestre de 2018. Disponível em: www.univali.br/direitoepolitica - ISSN 1980-7791

maior rigor, justamente para se estimular o cumprimento espontâneo do determinado legalmente? ${ }^{46}$.

Dessa forma, com fundamento nos arts. 50, caput, $6^{\circ}$ e 196, todos da Constituição Federal, julgou-se procedente o pedido inicial, determinando-se que os réus Município de Cacoal e Estado de Rondônia, solidariamente disponibilizassem ao autor o tratamento pleiteado, mensalmente, enquanto o mesmo se fizesse necessário.

Essa decisão se diferenciada maioria prolatada no âmbito estadual por fazer uma análise rigorosa do caso concreto, o que nas demais, via de regra, não ocorre.

O que não é diferente entre elas ou entre a maioria delas (incluindo as proferidas pelo STJ e STF) é o fato de que implicam quase sempre em aumento de custos para o ente público, obrigando-o a implementar o direito à saúde diretamente a partir da Constituição, à margem de norma legal ou regulamentar. Dessa forma, essas sentenças aditivas caracterizam o Poder Judiciário como um legítimo "ordenador de despesa".

Identificados os entendimentos dos estudiosos do tema e as decisões dos tribunais superiores - STJ e STF -, assim como as decisões da primeira e segunda instâncias do Estado de Rondônia, é importante que se conheça como se processa a judicialização da saúde no âmbito da administração estadual, como se verá na sequência.

\section{JUDICIALIZAÇÃO DA SAÚDE EM RONDÔNIA: MODUS OPERANDI DO CUMPRIMENTO DAS DECISÕES JUDICIAIS NO ÂMBITO DA ADMINISTRAÇÃO PÚBLICA ESTADUAL}

No Estado de Rondônia, o Núcleo de Mandados Judiciais (NMJ), setor da Secretaria Estadual de Saúde, centraliza todas as ações judiciais contra o Estado que solicitam o fornecimento de medicamentos, procedimentos e insumos.

Esse órgão, no ano de 2013, passou por uma reestruturação, apresentando, a partir daí a estrutura que se verá seguir.

\section{(a) Protocolo}

Setor responsável por todo o trâmite de documentos que entram no NMJ, dentre os quais processos e ofícios, através de planilhas.

\section{(b) Resposta de ofícios}

Responsável por verificar se o paciente já foi atendido, ou, caso não tenha sido, averiguar se há alguma forma de atendê-lo, seja por disponibilidade de estoque na Gerência de Medicamentos (GM), no Componente Especializado em Assistência Farmacêutica (CEAF),

${ }^{46}$ RONDÔNIA. Tribunal de Justiça do Estado de Rondônia. 1 a Vara Cível de Cacoal. Ação Ordinária 000610969.2013.8.22.0007. Juíza de Direito Emy Karla Yamamoto Roque, julgado em 29.08.2014. DJ, 03.09.2014. 
HECKTHEUER, Pedro Abib; CASTRO, Raimundo Viana de; HECKTHEUER, Fabio Rychecki. Os impactos da judicialização da saúde no estado de Rondônia no período de 2010 a 2015 e a previsão de gastos para o biênio 2016-2017. Revista Eletrônica Direito e Política, Programa de Pós-Graduação Stricto Sensu em Ciência Jurídica da UNIVALI, Itajaí, v.13, n.2, $2^{\circ}$ quadrimestre de 2018. Disponível em: www.univali.br/direitoepolitica - ISSN 1980-7791

nos Centros de Abastecimento Farmacêutico (CAF1 e CAF2) ou no Centro de Atendimento Psicossocial (CAPS), ou ainda, por Atas de Pregão.

Sendo necessária a compra emergencial, esse setor verifica se há receituário atualizado (três meses), documentos pessoais e cartão SUS do paciente. Em seguida, envia ofício para - Setor Jurídico, e receita médica, juntamente com mandado de segurança, para o setor responsável por elaboração de SAMS - Solicitação de Aquisição de Medicamentos e Serviços.

(c) Setor jurídico

Setor responsável por informar aos órgãos externos (PGE, MP, etc.) a respeito do cumprimento das ordens judiciais, além de representar o NMJ em audiências. Deve realizar pesquisa no sítio eletrônico do Tribunal de Justiça, a fim de se certificar de que há alguma decisão judicial, de modo que não se atenda pacientes que não tenham mandado.

\section{(d) Elaboração de Solicitação de Aquisição de Medicamentos e Serviços - SAMS}

Setor responsável por elaborar a solicitação de aquisição de medicamentos e serviços, baseada na ordem judicial e em receituário médico, que deverá conter o princípio ativo, a concentração, a quantidade diária, além da verificação se o mesmo é de uso contínuo ou não, e que deverão ser anexados juntamente aos documentos pessoais do paciente. Em seguida, deve repassar para a cotação de preços.

\section{(e) Cotação de preços}

Parte responsável por entrar em contato com fornecedores, com o objetivo de obter, no mínimo, três cotações válidas para compra emergencial direta. Caso não haja propostas, deve encaminhar ao Gerente do Núcleo com certidão informando o ocorrido, para que este tome as devidas providências. Se houver propostas, fechar quadro comparativo, alocação de recursos, despacho para o Procurador, emissão de lauda e enviar para emissão de nota de empenho.

\section{(f) Entrega de nota de empenho (NF) e pagamento de notas fiscais (NF)}

Responsável por enviar a nota de empenho aos fornecedores e observar o prazo de entrega de 15 dias, além de realizar a cobrança de entrega, assim como realizar notificações. Após a entrega dos itens da nota de empenho, deve fazer termo de recebimento, juntada de notas fiscais e certidões e enviar para pagamento.

Além desses setores, o Núcleo de Mandados Judiciais também dispõe de uma seção responsável pela estruturação das atas de pregão, voltado à realização de licitações para a compra dos produtos mais judicializados, visando, sobretudo, à diminuição de compras emergenciais. 
HECKTHEUER, Pedro Abib; CASTRO, Raimundo Viana de; HECKTHEUER, Fabio Rychecki. Os impactos da judicialização da saúde no estado de Rondônia no período de 2010 a 2015 e a previsão de gastos para o biênio 2016-2017. Revista Eletrônica Direito e Política, Programa de Pós-Graduação Stricto Sensu em Ciência Jurídica da UNIVALI, Itajaí, v.13, n.2, $2^{\circ}$ quadrimestre de 2018. Disponível em: www.univali.br/direitoepolitica - ISSN 1980-7791

Assim, o gestor se antecipa à decisão judicial e adquire os produtos mais pedidos, numa clara demonstração de que o Judiciário obriga à Secretaria Estadual de Saúde a tornar o acesso ao SUS de forma desigual. Em outras palavras, para aqueles que recorrem à via judicial já existem medicamentos e insumos licitados, enquanto para os demais, somente uma longa fila ${ }^{47}$. Além disso, a retirada de servidores das áreas fins da Secretaria de Saúde, para integrar o quadro de pessoal do setor de licitações do Núcleo de Mandados Judiciais, causa prejuízo às políticas definidas previamente.

Assim, os processos que chegam ao Núcleo de Mandados Judiciais seguem o fluxograma descrito na figura 1.

Figura 1

Fluxograma dos ofícios no âmbito do Núcleo de Mandados Judiciais - NMJ

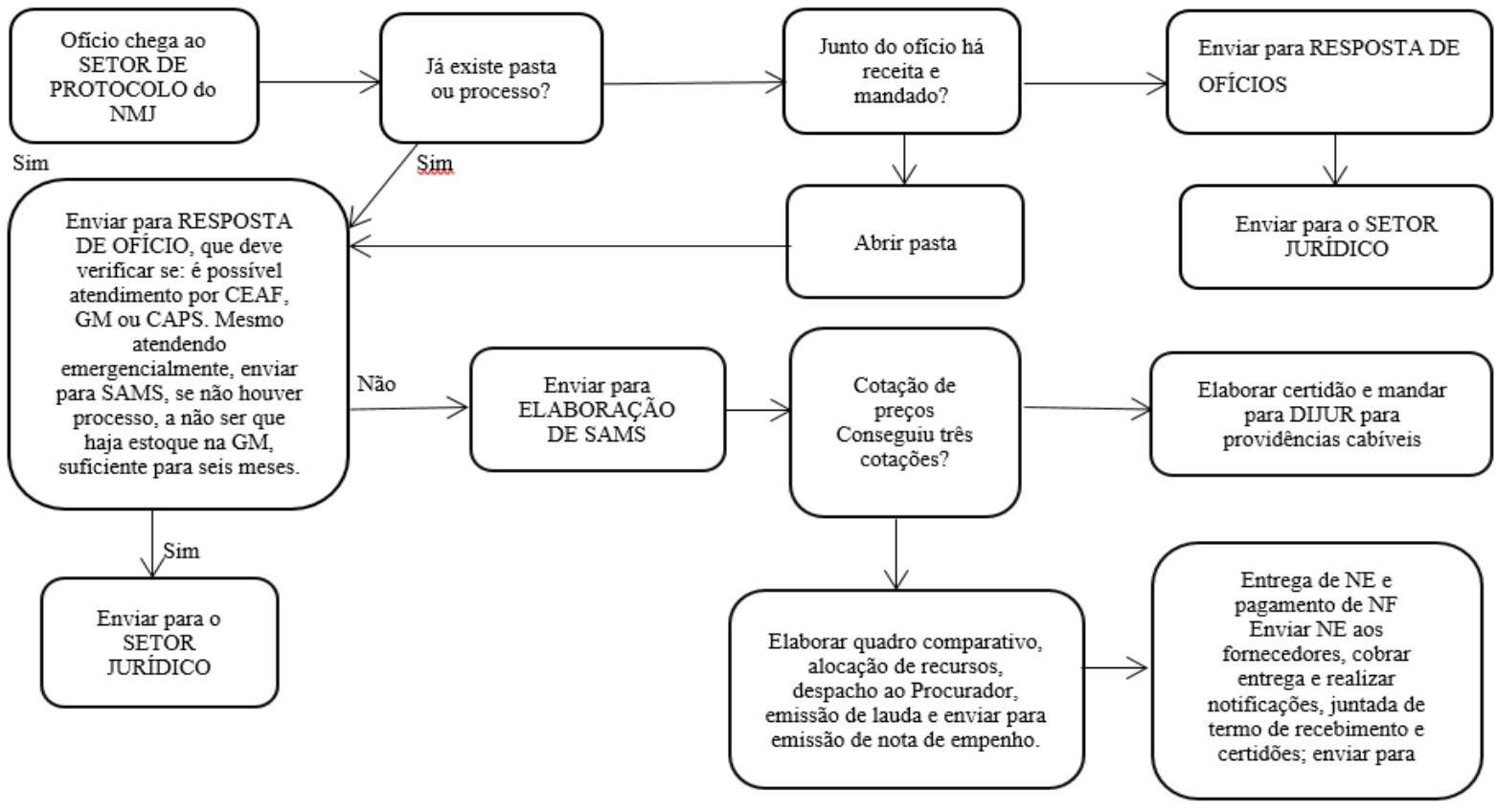

Fonte: Núcleo de Mandados Judiciais da Secretaria Estadual de Saúde.

A judicialização da saúde no Estado de Rondônia, portanto, impõe ao gestor público estadual a necessidade de atuar de forma diferenciada, cujo maior desafio consiste em harmonizar os princípios e as diretrizes terapêuticas do SUS com a obrigatoriedade de responder às ordens judiciais, assim como evitar o crescimento de novas demandas.

\footnotetext{
${ }^{47}$ Essa realidade se revela ainda mais injusta se considerarmos que "o acesso ao Poder Judiciário no Brasil ainda é limitado às classes média e alta da população". HACHEM, Daniel Wunder. A noção constitucional de desenvolvimento para além do viés econômico: reflexos sobre algumas tendências do Direito Público brasileiro. A\&C - Revista de Direito Administrativo \& Constitucional, Belo Horizonte, ano 13, n. 53, p. 133168, jul./set. 2013.
} 
HECKTHEUER, Pedro Abib; CASTRO, Raimundo Viana de; HECKTHEUER, Fabio Rychecki. Os impactos da judicialização da saúde no estado de Rondônia no período de 2010 a 2015 e a previsão de gastos para o biênio 2016-2017. Revista Eletrônica Direito e Política, Programa de Pós-Graduação Stricto Sensu em Ciência Jurídica da UNIVALI, Itajaí, v.13, n.2, $2^{\circ}$ quadrimestre de 2018. Disponível em: www.univali.br/direitoepolitica - ISSN 1980-7791

Após ter compreendido a organização administrativa de que dispõe a Secretaria Estadual de Saúde para fazer cumprir as medidas determinadas pelo Poder Judiciário, resta necessário saber, empiricamente, qual é a realidade em termos de gasto público da judicialização da saúde no Estado de Rondônia, assim como qual a representatividade que este fenômeno tem no orçamento estadual e no setor da saúde.

\section{OS CUSTOS DA JUDICIALIZAÇÃO DA SAÚdE EM RONDÔNIA NO SEXÊNIO 2010- 2015 E A SUA BAIXA REPRESENTATIVIDADE NAS DESPESAS DO SETOR}

No período de 2010 a 2015, o Estado de Rondônia destinou, inicialmente em seu orçamento, um valor equivalente a $\mathrm{R} \$ 22.784 .740,00$ para o cumprimento de decisões judiciais relativas à saúde. No decorrer dos exercícios financeiros, houve a necessidade de uma suplementação de verbas da ordem de $\mathrm{R} \$ 23.003 .097,82$, totalizando $\mathrm{R} \$ 45.787 .837,82$. Nesse mesmo período, o total empenhado - valor realmente gasto - com essas decisões foi de $R \$$ 37.787.152,85.

Além dos valores constantes nos documentos orçamentários do Estado, existem também aqueles sequestrados diretamente nas contas bancárias estaduais. Aplicando a metodologia explicitada, obteve-se o valor de $\mathrm{R} \$ 16.909 .228,49$ para esse tipo de gasto. Assim, de acordo com o método empregado, o gasto total do Estado com judicialização da saúde, no período de 2010 a 2015, foi estimado em R\$54.696.381,34 (tabela 1), superando o valor previsto em $19,46 \%$, isto é, em $\mathrm{R} \$ 8.908 .543,52$.

Tabela 1

\begin{tabular}{|c|c|c|c|c|c|c|c|}
\hline \multirow[b]{2}{*}{ Ano } & \multicolumn{3}{|c|}{ Previsto } & \multicolumn{3}{|c|}{ Gasto } & \multirow{2}{*}{$\begin{array}{c}\% \\
\text { Diferença } \\
\text { entre } \\
\text { orçamento } \\
\text { final e } \\
\text { despesa } \\
\text { total }\end{array}$} \\
\hline & Inicial & Incremento & $\begin{array}{c}\text { Orçamento } \\
\text { final }\end{array}$ & Empenhado & Sequestros & $\begin{array}{c}\text { Despesa total } \\
\text { (empenhado + } \\
\text { bloqueios) }\end{array}$ & \\
\hline 2010 & $1.784 .740,00$ & $13.439 .066,43$ & $15.223 .806,43$ & $12.144 .087,24$ & $18.682,14$ & $12.162 .769,38$ & $-20,11$ \\
\hline 2011 & $1.500 .000,00$ & $10.190 .847,00$ & $11.690 .847,00$ & $10.873 .086,81$ & $652.293,19$ & $11.525 .380,00$ & $-1,42$ \\
\hline 2012 & $8.000 .000,00$ & $1.417 .932,70$ & $9.417 .932,70$ & $7.598 .138,44$ & $1.641 .713,81$ & $9.239 .852,25$ & $-1,89$ \\
\hline 2013 & $7.000 .000,00$ & $-1.900 .000,00$ & $5.100 .000,00$ & $3.350 .854,30$ & $4.140 .932,48$ & $7.491 .786,78$ & 46,90 \\
\hline 2014 & $2.500 .000,00$ & $-664.748,31$ & $1.835 .251,69$ & $1.358 .448,67$ & $5.161 .486,06$ & $6.519 .934,73$ & 255,26 \\
\hline 2015 & $2.000 .000,00$ & $520.000,00$ & $2.520 .000,00$ & $2.462 .537,39$ & $5.294 .120,81$ & $7.756 .658,20$ & 207,80 \\
\hline Total & $22.784 .740,00$ & $23.003 .097,82$ & $45.787 .837,82$ & $37.787 .152,85$ & $16.909 .228,49$ & $54.696 .381,34$ & 19,46 \\
\hline
\end{tabular}

Fonte: Elaboração própria

Com base no gráfico 1, observa-se que o custo com a judicialização da saúde em Rondônia apresentou uma redução entre 2010 e 2014 e um pequeno aumento entre 2014 e 2015. A diminuição estimada foi de $46,39 \%$ ( $R \$ 5.642 .834,65)$, enquanto o aumento girou em torno de $18,97 \%(\mathrm{R} \$ 1.236 .723,47)$. 
HECKTHEUER, Pedro Abib; CASTRO, Raimundo Viana de; HECKTHEUER, Fabio Rychecki. Os impactos da judicialização da saúde no estado de Rondônia no período de 2010 a 2015 e a previsão de gastos para o biênio 2016-2017. Revista Eletrônica Direito e Política, Programa de Pós-Graduação Stricto Sensu em Ciência Jurídica da UNIVALI, Itajaí, v.13, n.2, $2^{\circ}$ quadrimestre de 2018. Disponível em: www.univali.br/direitoepolitica - ISSN 1980-7791

\section{Gráfico 1}

Evolução anual dos custos com a judicialização da saúde no Estado de Rondônia

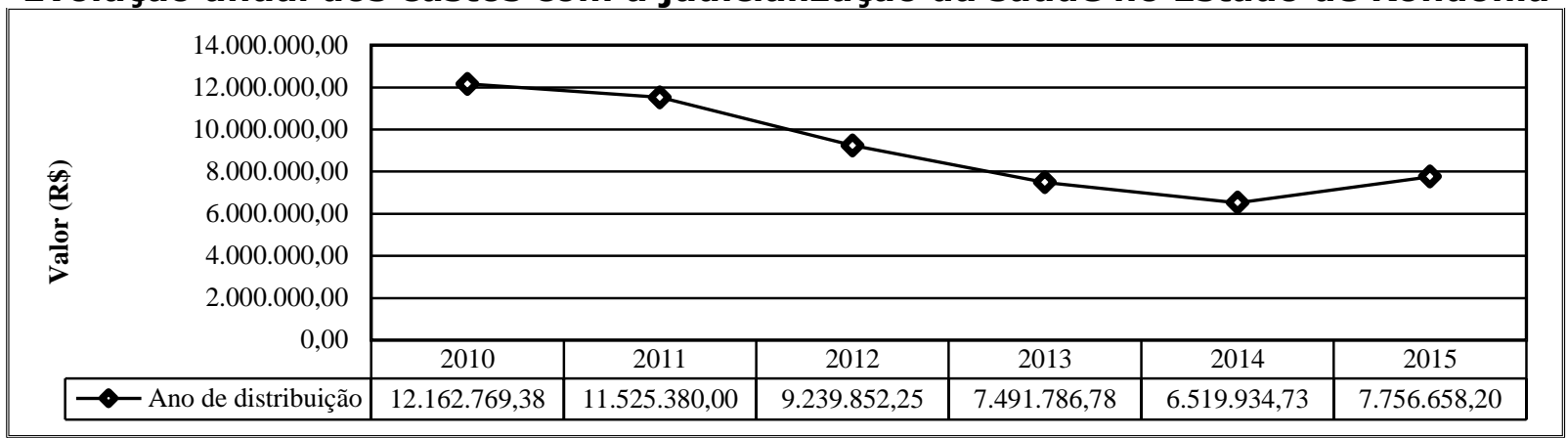

Fonte: elaboração própria

Os resultados obtidos no período mostram que a despesa do Estado com a judicialização da saúde corresponde a pouco mais de $1 \%$ do gasto do governo com todas as ações do setor, o que não representa um impacto significante nas finanças do Estado, principalmente se considerarmos que a receita total do Estado nesse período foi estimada em $\mathrm{R} \$$ 37.109.518.852,00. Isto é, a despesa com o cumprimento de decisões judiciais garantidoras do acesso à saúde, no período de 2010 a 2015, não passou de 0,15\% da receita total do Estado (tabela 2).

Tabela 2

Percentual do custo da judicialização da saúde em relação ao total das despesas com saúde e relativo à receita total do Estado de RO no período de 2010 a 2015

\begin{tabular}{c|c|c|c|c|c}
\hline Ano & $\begin{array}{c}\text { Receita total do Estado* } \\
(\mathbf{r})\end{array}$ & $\begin{array}{c}\text { Despesa com saúde** } \\
\mathbf{( e )}\end{array}$ & $\begin{array}{c}\text { Despesas com a } \\
\text { judicialização da saúde } \\
(\mathbf{f})\end{array}$ & $\begin{array}{c}\text { \% } \\
(\mathbf{f} / \mathbf{e})\end{array}$ & $\begin{array}{c}\text { \% } \\
(\mathbf{f} / \mathbf{r})\end{array}$ \\
\hline 2010 & $4.968 .389 .690,00$ & $619.291 .956,17$ & $12.162 .769,38$ & 1,96 & 0,24 \\
\hline 2011 & $5.200 .000 .000,00$ & $650.138 .215,84$ & $11.525 .380,00$ & 1,77 & 0,22 \\
\hline 2012 & $6.084 .902 .963,00$ & $684.667 .313,18$ & $9.239 .852,25$ & 1,35 & 0,15 \\
\hline 2013 & $6.561 .152 .894,00$ & $889.549 .109,48$ & $7.491 .786,78$ & 0,84 & 0,11 \\
\hline 2014 & $6.975 .299 .323,00$ & $869.699 .409,56$ & $6.519 .934,73$ & 0,75 & 0,09 \\
\hline 2015 & $7.319 .773 .982,00$ & $952.633 .322,84$ & $7.756 .658,20$ & 0,81 & 0,11 \\
\hline Total & $\mathbf{3 7 . 1 0 9 . 5 1 8 . 8 5 2 , 0 0}$ & $\mathbf{4 . 6 6 5 . 9 7 9 . 3 2 7 , 0 7}$ & $\mathbf{5 4 . 6 9 6 . 3 8 1 , 3 4}$ & $\mathbf{1 , 1 7}$ & $\mathbf{0 , 1 5}$ \\
\hline
\end{tabular}

Fonte: Elaboração própria

* Valores obtidos no site da Secretaria de Estado de Planejamento, Orçamento e Gestão - SEPOG - RO.

** Valores obtidos no site do Sistema de Informações sobre Orçamentos Públicos em Saúde - SIOPS.

Conclusão semelhante é a que se obtém com a comparação entre o gasto per capita com a judicialização da saúde e o gasto per capita com todo setor de saúde, nesse período. Os dados da tabela 3 mostram que o maior gasto anual por habitante se deu em 2010 e foi estimado em $\mathrm{R} \$ 7,31$, enquanto no mesmo ano a despesa por pessoa com todas as ações relativas à saúde foi de $R \$ 372,28$. Já o maior valor gasto por pessoa com todo o setor de saúde foi de $\mathrm{R} \$ 538,76$, em 2015 , mesmo ano em que o gasto per capita com a judicialização foi de $R \$ 4,39$ (tabela 3). 
HECKTHEUER, Pedro Abib; CASTRO, Raimundo Viana de; HECKTHEUER, Fabio Rychecki. Os impactos da judicialização da saúde no estado de Rondônia no período de 2010 a 2015 e a previsão de gastos para o biênio 2016-2017. Revista Eletrônica Direito e Política, Programa de Pós-Graduação Stricto Sensu em Ciência Jurídica da UNIVALI, Itajaí, v.13, n.2, $2^{\circ}$ quadrimestre de 2018. Disponível em: www.univali.br/direitoepolitica - ISSN 1980-7791

Tabela 3

Gasto per capita com todo o setor de saúde e com a judicialização da saúde em Rondônia no período de 2010 a 2015

\begin{tabular}{c|c|c|c|c|c}
\hline Ano & $\begin{array}{c}\text { População do } \\
\text { Estado* }\end{array}$ & $\begin{array}{c}\text { Despesa com } \\
\text { saúde** }\end{array}$ & $\begin{array}{c}\text { Despesa com a } \\
\text { judicialização da } \\
\text { saúde }\end{array}$ & $\begin{array}{c}\text { Gasto per } \\
\text { capita com } \\
\text { saúde }\end{array}$ & $\begin{array}{c}\text { Gasto per capita } \\
\text { com a judicialização } \\
\text { da saúde }\end{array}$ \\
\hline 2010 & 1.663 .490 & $619.291 .956,17$ & $\mathbf{1 2 . 1 6 2 . 7 6 9 , 3 8}$ & 372,28 & 7,31 \\
\hline 2011 & 1.685 .697 & $650.138 .215,84$ & $11.525 .380,00$ & 385,68 & 6,84 \\
\hline 2012 & 1.707 .272 & $684.667 .313,18$ & $9.239 .852,25$ & 401,03 & 5,41 \\
\hline 2013 & 1.728 .214 & $889.549 .109,48$ & $7.491 .786,78$ & 514,72 & 4,33 \\
\hline 2014 & 1.748 .531 & $869.699 .409,56$ & $6.519 .934,73$ & 497,39 & 3,73 \\
\hline 2015 & 1.768 .204 & $952.633 .322,84$ & $7.756 .658,20$ & 538,76 & 4,39 \\
\hline
\end{tabular}

Fonte: Elaboração própria

* Informações obtidas no site do Instituto Brasileiro de Geografia e Estatística - IBGE.

** Valores obtidos no site do Sistema de Informações sobre Orçamentos Públicos em Saúde - SIOPS.

Uma das hipóteses para justificar a diminuição dos gastos com a judicialização da saúde no Estado de Rondônia nesse período é o fato de as despesas com o setor de saúde haver aumentado significativamente de 2010 a 2015, como se pode observar na Tabela 3, passando de $R \$ 619.291 .956,17$ para $R \$ 952.633 .322,84$.

Em outras palavras, paralelamente ao decréscimo dos gastos com judicialização, houve um aumento com a despesa do governo estadual com o setor da saúde, solucionando as demandas dos cidadãos pela via administrativa.

Outra hipótese para essa diminuição pode estar na mudança de postura dos magistrados quando das decisões referentes a esse tipo de pleito no Judiciário do Estado Rondônia, ao não concederem todo e qualquer tipo de demanda de saúde, como aconteciam nos anos iniciais da pesquisa. Um estudo qualitativo das decisões poderá dar maior clareza a essa hipótese, pois a presente pesquisa se baseou no estudo quantitativo, e as análises não tiveram como foco essa problemática. No entanto, durante o levantamento dos dados, ainda que sem o rigor científico do método qualitativo, tal hipótese pareceu ficar demonstrada.

\section{SEQUESTROS DO DINHEIRO PÚBLICO PARA O CUMPRIMENTO DE DECISÕES JUDICIAIS: O LADO OBSCURO DOS GASTOS COM SAÚDE EM RONDÔNIA}

Quando a decisão judicial garantidora do acesso à saúde não é cumprida, frequentemente o que se vê no Estado é o singelo sequestro do dinheiro público disponível nos bancos, através de ordem judicial, com a imposição de multas em caso de descumprimento.

Segundo a Gerência de Contas do Tesouro Estadual, durante a entrevista realizada, o maior problema relacionado aos bloqueios judiciais de valores "na boca do caixa" reside 
HECKTHEUER, Pedro Abib; CASTRO, Raimundo Viana de; HECKTHEUER, Fabio Rychecki. Os impactos da judicialização da saúde no estado de Rondônia no período de 2010 a 2015 e a previsão de gastos para o biênio 2016-2017. Revista Eletrônica Direito e Política, Programa de Pós-Graduação Stricto Sensu em Ciência Jurídica da UNIVALI, Itajaí, v.13, n.2, $2^{\circ}$ quadrimestre de 2018. Disponível em: www.univali.br/direitoepolitica - ISSN 1980-7791

na falta de critérios na escolha das contas por parte dos juízes, pois estes, ao acessarem o Bacenjud, sequestram os valores das contas bancárias estaduais, de forma aleatória, o que ocasiona, na maioria das vezes, o sequestro de dinheiro público em contas diferentes da Conta Única, as quais são destinadas a movimentar recursos de outros convênios celebrados pelo Estado, desorganizando planejamento financeiro desse Ente Federado, pois a partir daí, o governo estadual passa a ter que realizar o processo orçamentário inverso, de modo a alocar esses valores no orçamento da devida Secretaria.

Na tentativa de diminuir as consequências desse problema, a Gerência de Contas do Tesouro Estadual, através da Procuradoria Geral do Estado, solicitou ao Tribunal de Justiça de Rondônia que recomendasse aos juízes do Estado que a realização desses sequestros fosse feita na Conta Única do Estado, conforme disciplina a Resolução no 61 de 2008 (Brasil, 2008), do Conselho Nacional de Justiça. Essa conta foi criada em 1998, junto ao Banco do Brasil, após a liquidação do antigo BERON.

Na pesquisa realizada, o que se observou é que os juízes da capital do Estado, em sua maioria, seguem essa recomendação. Já os juízes que atuam no interior, nem tanto. Grande parte deles, ainda continua a ordenar o bloqueio das contas correntes estaduais, escolhidas aleatoriamente, dificultando a capacidade organizacional do governo.

Informações da Gerência de Contas do Tesouro Estadual dão conta de que esses valores sequestrados das contas correntes do Estado, até o ano de 2015, não eram incorporados ao orçamento da Secretaria Estadual de Saúde, de modo que nos arquivos daquela Secretaria simplesmente não se encontram informações quanto ao total envolvido nessa prática.

A partir de 2016, todavia, a Gerência de Contas Estadual passou a controlar esses valores através de processos administrativos, que incluem todos os sequestros ocorridos mensalmente, os quais são destinados à Secretaria de Saúde Estadual, para que esta proceda à devida regularização orçamentária.

De janeiro de 2010 a dezembro de 2015, foram realizados 4.536 sequestros nas contas correntes do Estado de Rondônia, sendo que destes, 4.463 puderam ser acessados no site do TJ-RO ou do TRF da $1^{a}$ Região, restando 74 que não puderam ser localizados.

Do total de sequestros pesquisados, 3.320 se referem à judicialização da saúde, o que equivale a $73,19 \%$ (tabela 4 ). 
HECKTHEUER, Pedro Abib; CASTRO, Raimundo Viana de; HECKTHEUER, Fabio Rychecki. Os impactos da judicialização da saúde no estado de Rondônia no período de 2010 a 2015 e a previsão de gastos para o biênio 2016-2017. Revista Eletrônica Direito e Política, Programa de Pós-Graduação Stricto Sensu em Ciência Jurídica da UNIVALI, Itajaí, v.13, n.2, $2^{\circ}$ quadrimestre de 2018. Disponível em: www.univali.br/direitoepolitica - ISSN 1980-7791

\section{Tabela 4}

\section{Sequestros realizados nas contas do Estado de RO no período de 2010 a 2015}

\begin{tabular}{c|c|c|c|c|c}
\hline & $\begin{array}{c}\text { Número de } \\
\text { processos } \\
\text { pesquisados } \\
\text { Ano }\end{array}$ & $\begin{array}{c}\text { Número de } \\
\text { processos não } \\
\text { localizados (n) }\end{array}$ & $\begin{array}{c}\text { Número de processos } \\
\text { referentes à judicialização } \\
\text { da saúde (j) }\end{array}$ & $\begin{array}{c}\text { \% } \\
\mathbf{( j / ( n + ~ p ) )}\end{array}$ & $\begin{array}{c}\text { Valor } \\
\text { (R\$) }\end{array}$ \\
\hline 2010 & 233 & 0 & 5 & 2,15 & $18.682,14$ \\
\hline 2011 & 162 & 5 & 107 & 64,07 & $652.293,19$ \\
\hline 2012 & 327 & 2 & 261 & 79,33 & $1.641 .713,81$ \\
\hline 2013 & 955 & 23 & 844 & 86,30 & $4.140 .932,48$ \\
\hline 2014 & 1.110 & 18 & 1.057 & 93,71 & $5.161 .486,06$ \\
\hline 2015 & 1.676 & 25 & 1.046 & 61,49 & $5.294 .120,81$ \\
\hline TOTAL & $\mathbf{4 . 4 6 3}$ & $\mathbf{7 3}$ & $\mathbf{3 . 3 2 0}$ & $\mathbf{7 3 , 1 9}$ & $\mathbf{1 6 . 9 0 9 . 2 2 8 , 4 9}$ \\
\hline
\end{tabular}

Fonte: Elaboração própria

Verifica-se, portanto, que aproximadamente três quartos de todos os sequestros havidos no período delimitado da pesquisa são relativos à judicialização do direito social à saúde (Tabela 4), demonstrando que, apesar de ter um impacto pequeno no orçamento do Estado, como se observou, é o direito social que mais afeta a falta de planejamento no orçamento estadual, em concordância com o que já houvera sido levantado na entrevista junto à Gerência de Contas do Tesouro Estadual.

\section{JUDICIALIAÇÃo DA SAÚdE EM RONDÔNIA: PREVISÃO DE CUSTOS PARA O TRIÊNIO 2016-2017 ATRAVÉS DA ANÁLISE DE REGRESSÃO}

A análise de regressão, segundo Montgomery e Runger ${ }^{48}$, "é uma técnica estatística para modelar e investigar a relação entre duas ou mais variáveis". Em outras palavras, consiste na obtenção de uma equação (modelo linear probabilístico) que tenta explicar a alteração da variável dependente ou de resposta pela variação do nível das variáveis independentes ou regressores.

Quando se considera apenas um regressor $\boldsymbol{x}$ e uma variável de resposta $\boldsymbol{y}$, o modelo é designado de modelo de regressão linear simples. Por outro lado, um modelo que contenha mais de um regressor é chamado de modelo de regressão linear múltipla.

Conforme se observa na tabela 1 , o incremento realizado no orçamento destinado ao cumprimento de decisões judiciais pelo Estado varia de acordo com o ano e com o valor previsto inicialmente. Assim, esse valor que deve ser acrescido ao orçamento será a variável de resposta, enquanto o ano e o valor inicial serão os regressores. Dessa forma, o modelo a ser encontrado será de regressão linear múltipla, já que temos duas variáveis independentes.

48 MONTGOMERY, Douglas C.; RUGER, George Ruger. Estatística Aplicada e Probabilidade para Engenheiros. 2a. ed. Rio de Janeiro: LTC, 2007, p. 205. 
HECKTHEUER, Pedro Abib; CASTRO, Raimundo Viana de; HECKTHEUER, Fabio Rychecki. Os impactos da judicialização da saúde no estado de Rondônia no período de 2010 a 2015 e a previsão de gastos para o biênio 2016-2017. Revista Eletrônica Direito e Política, Programa de Pós-Graduação Stricto Sensu em Ciência Jurídica da UNIVALI, Itajaí, v.13, n.2, $2^{\circ}$ quadrimestre de 2018. Disponível em: www.univali.br/direitoepolitica - ISSN 1980-7791

A equação da regressão linear múltipla tem a seguinte forma: $\boldsymbol{y}_{c}=\boldsymbol{a}+\boldsymbol{b}_{1} \boldsymbol{x}_{\mathbf{1}}+\boldsymbol{b}_{2} \boldsymbol{x}_{2}+$ $\cdots+\boldsymbol{b}_{i} \boldsymbol{x}_{\boldsymbol{k}}$, onde $\boldsymbol{a}$ é o intercepto do eixo $y ; \boldsymbol{b}_{\boldsymbol{i}}$ é o coeficiente angular da $i$-ésima variável e $\boldsymbol{k}$ é o número de regressores.

Como o número de regressores que temos é $k=2$, o modelo que procuramos pode ser escrito como: $\boldsymbol{y}_{\boldsymbol{c}}=\boldsymbol{a}+\boldsymbol{b}_{1} \boldsymbol{x}_{\mathbf{1}}+\boldsymbol{b}_{2} \boldsymbol{x}_{2}$, no qual $\boldsymbol{y}_{c}$ é o incremento orçamentário (variável de resposta), $\boldsymbol{a}$ é o intercepto do plano, $\boldsymbol{x}_{1}$ é o ano a ser considerado e $\boldsymbol{x}_{2}$ é o valor inicialmente previsto.

Os parâmetros $\boldsymbol{b}_{\boldsymbol{1}}$ e $\boldsymbol{b}_{2}$, de acordo com Montgomery e Runger ${ }^{49}$, são os coeficientes parciais de regressão, porque $\boldsymbol{b}_{1}$ mede a variação esperada em $\boldsymbol{y}_{\boldsymbol{c}}$, por unidade de variação em $x_{1}$, quando $x_{2}$ é mantido constante, e $\boldsymbol{b}_{2}$ mede a variação esperada em $\boldsymbol{y}_{\boldsymbol{c}}$, por unidade de variação em $x_{2}$, mantendo-se $x_{1}$ constante.

Para a obtenção do modelo matemático, considerou-se que os valores dos sequestros constituem uma forma de suplementação de verba, devendo ser somados aos valores destinados a essa finalidade que se encontram na tabela 1 , obtendo-se o incremento total (tabela 5).

Tabela 5

Valor inicial e incremento destinados à judicialização da saúde em Rondônia no período de 2010 a 2015

\begin{tabular}{c|c|c}
\hline Ano & Valor inicial & Incremento \\
\hline $\mathbf{2 0 1 0}$ & $1.784 .740,00$ & $13.457 .748,57$ \\
\hline $\mathbf{2 0 1 1}$ & $1.500 .000,00$ & $10.843 .140,19$ \\
\hline $\mathbf{2 0 1 2}$ & $8.000 .000,00$ & $3.059 .636,81$ \\
\hline $\mathbf{2 0 1 3}$ & $7.000 .000,00$ & $2.240 .932,48$ \\
\hline $\mathbf{2 0 1 4}$ & $2.500 .000,00$ & $4.496 .737,75$ \\
\hline $\mathbf{2 0 1 5}$ & $2.000 .000,00$ & $5.814 .120,81$ \\
\hline
\end{tabular}

Como os valores dispostos na tabela 5 não se encontram estabilizados, isto é, sua função verdadeira de regressão não é linear, faz-se necessário estabilizá-los, de modo que sua função passe a ser linear. Isso pode ser feito através de uma transformação logarítmica. Assim, aplicando-se logaritmo decimal aos valores da referida tabela, tem-se aqueles dispostos na tabela 6 .

49 MONTGOMERY, Douglas C.; RUGeR, George Ruger. Estatística Aplicada e Probabilidade para Engenheiros. Rio de Janeiro: 2. ed., LTC, 2008, p. 265. 
HECKTHEUER, Pedro Abib; CASTRO, Raimundo Viana de; HECKTHEUER, Fabio Rychecki. Os impactos da judicialização da saúde no estado de Rondônia no período de 2010 a 2015 e a previsão de gastos para o biênio 2016-2017. Revista Eletrônica Direito e Política, Programa de Pós-Graduação Stricto Sensu em Ciência Jurídica da UNIVALI, Itajaí, v.13, n.2, $2^{\circ}$ quadrimestre de 2018. Disponível em: www.univali.br/direitoepolitica - ISSN 1980-7791

Tabela 6

Variável de resposta e regressores após transformação logarítmica

\begin{tabular}{c|c|c}
\hline Ano & Valor inicial & Incremento \\
\hline $\mathbf{3 , 3 0 3 1 9 6 0 5 7}$ & 6,251574957 & 7,128972410 \\
\hline $\mathbf{3 , 3 0 3 4 1 2 0 7 1}$ & 6,176091259 & 7,035155073 \\
\hline $\mathbf{3 , 3 0 3 6 2 7 9 7 6}$ & 6,903089987 & 6,485669877 \\
\hline $\mathbf{3 , 3 0 3 8 4 3 7 7 5}$ & 6,845098040 & 6,350428771 \\
\hline $\mathbf{3 , 3 0 4 0 5 9 4 6 6}$ & 6,397940009 & 6,652897560 \\
\hline $\mathbf{3 , 3 0 4 2 7 5 0 5 0}$ & 6,301029996 & 6,764484052 \\
\hline
\end{tabular}

Fonte: Elaboração própria

Os valores de $\boldsymbol{a}, \boldsymbol{b}_{1}$ e $\boldsymbol{b}_{2}$ foram obtidos com o auxílio do software XLSTAT, desenvolvido para análise estatística no Microsoft Excel.

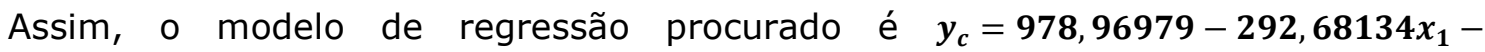

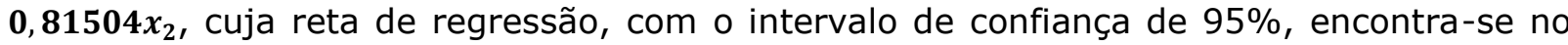
gráfico 2.

GRÁFICO 2

Gráfico da reta de regressão, com intervalo de confiança de $95 \%$.

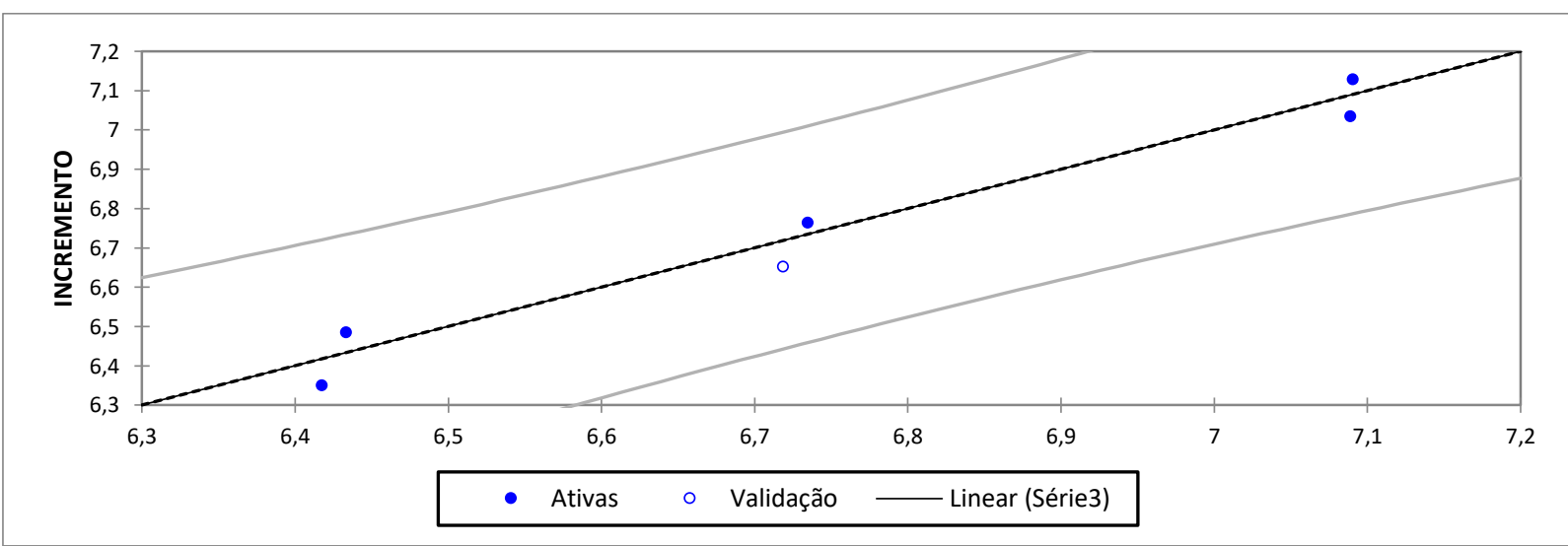

Fonte: Elaboração própria

Uma aplicação importante de um modelo de regressão é prever novas ou futuras observações. Assim, a partir do modelo encontrado acima é possível encontrar os valores do incremento que o Estado deve fazer àqueles inicialmente previstos, para os anos de 2016 e 2017.

No que se refere ao ano de 2016, conforme a metodologia definida na introdução, o valor inicial foi de $\mathrm{R} \$ 2.000 .000,00$. Já para o ano de 2017 , considerou-se como inicial a média desses valores em todo o período 2010-2016, isto é, R\$3.540.677,14.

Destarte, o incremento obtido para os anos de 2016 e 2017 foi de $R \$ 4.693 .348,75$ e 2.548.426,34, respectivamente, conforme disposto na tabela 7. 
HECKTHEUER, Pedro Abib; CASTRO, Raimundo Viana de; HECKTHEUER, Fabio Rychecki. Os impactos da judicialização da saúde no estado de Rondônia no período de 2010 a 2015 e a previsão de gastos para o biênio 2016-2017. Revista Eletrônica Direito e Política, Programa de Pós-Graduação Stricto Sensu em Ciência Jurídica da UNIVALI, Itajaí, v.13, n.2, $2^{\circ}$ quadrimestre de 2018. Disponível em: www.univali.br/direitoepolitica - ISSN 1980-7791

\section{Tabela 7}

Previsão do incremento orçamentário e do custo total do Estado de Rondônia com a judicialização da saúde no biênio $2016-2017$

\begin{tabular}{c|c|c|c|c}
\hline Ano & Valor inicial (R\$) & Incremento previsto (R\$) & Previsão de gasto total $(R \$)$ & Decréscimo em relação a 2015 \\
\hline 2016 & $2.000 .000,00$ & $4.693 .348,75$ & $6.693 .348,75$ & 13,71 \\
\hline 2017 & $3.540 .677,14$ & $2.548 .426,34$ & $6.089 .103,48$ & 21,50 \\
\hline
\end{tabular}

Fonte: Elaboração própria

É possível observar que a despesa do Estado com a judicialização da saúde, nos anos de 2016 e 2017, de acordo como modelo utilizado, será um valor por volta de $\mathrm{R} \$$ $7.000 .000,00$ e $R \$ 6.000 .000,00$, respectivamente.

Os dados obtidos servirão para testar o modelo utilizado tão logo se possa acessar os dados da judicialização referente ao biênio, de forma que em breve se poderá avaliar o modelo e aferir se, efetivamente, poderá contribuir com o governo estadual no que diz respeito a previsão e o consequente planejamento efetiva de gastos com relação a judicialização da saúde.

\section{CONSIDERAÇÕES FINAIS}

O direito à saúde, seja por determinação expressa da Constituição (art. $6^{\circ}$ ), seja por exigir, para sua fruição, a criação e implementação de políticas públicas, é um direito social. Isso não implica, todavia, que esse direito não possa ser tutelado judicialmente, pois, naquilo que se referem ao mínimo existencial, os direitos sociais são considerados subjetivos.

Essa tutela, por outro lado, deve observar os critérios estabelecidos pelo STF no julgamento da STA-AgR 175/CE, pois como não há na Constituição, direito subjetivo individual de acesso universal, incondicional, gratuito e a qualquer custo a todo e qualquer meio de proteção à saúde, visto que isso encontraria óbice na reserva do possível, o que se defende é a proteção desse direito naquilo que corresponda ao mínimo existencial ${ }^{50,51}$, o que só poderá ser feito à luz da análise do caso concreto.

Esses critérios, em regra, não são observados pelo Judiciário rondoniense, principalmente em primeira instância, onde a maioria das decisões, fundamentadas na responsabilidade solidária dos entes federados no que tange ao direito à saúde, e no art. 196 da Constituição, parecem seguir um "modelo predeterminado", no qual se insere apenas os dados do autor

${ }^{50}$ BARCELlOS, Ana Paula de. A eficácia jurídica dos princípios constitucionais. Rio de Janeiro: Renovar, 2002.

${ }^{51}$ CALIENDO, Paulo. Reserva do possível, direitos fundamentais e tributação. In: SARLET, Ingo Wolfgang; TIM, Luciano Benetti. Direitos Fundamentais: orçamento e reserva do possível. Porto Alegre: Livraria do Advogado, 2013. 
HECKTHEUER, Pedro Abib; CASTRO, Raimundo Viana de; HECKTHEUER, Fabio Rychecki. Os impactos da judicialização da saúde no estado de Rondônia no período de 2010 a 2015 e a previsão de gastos para o biênio 2016-2017. Revista Eletrônica Direito e Política, Programa de Pós-Graduação Stricto Sensu em Ciência Jurídica da UNIVALI, Itajaí, v.13, n.2, $2^{\circ}$ quadrimestre de 2018. Disponível em: www.univali.br/direitoepolitica - ISSN 1980-7791

e a designação do medicamento, procedimento ou insumo, além da data, para obrigar o Estado a fornecer tais bens e serviços de saúde.

Para o cumprimento dessas decisões judiciais, o Estado de Rondônia dispõe de um setor na Secretaria de Saúde - o Núcleo de Mandados Judiciais -, que segue um roteiro de atendimento, desde a chegada dos ofícios e/ou processos, até a entrega dos bens e serviços de saúde aos pacientes, inclusive dispondo de uma seção destinada a se antecipar à decisão judicial e realizar licitações para os produtos mais pedidos, sabendo previamente que será obrigado judicialmente a fornecê-los. Essa prática, apesar de eficiente do ponto de vista administrativo, torna o acesso desigual ao SUS, já que esses produtos já licitados são acessíveis apenas àqueles que os pleiteiam judicialmente, além de retirar servidores das áreas fins da Secretaria, para comporem o quadro de pessoal do Setor de Atas de Pregão do Núcleo de Mandados Judiciais, com prejuízo evidente às políticas previamente definidas.

Já a pesquisa empírica mostrou que o gasto total do Estado com a judicialização da saúde supera os valores previstos em seu orçamento, o que já era esperado, tendo em vista os dados disponíveis sobre esse fenômeno $52,53,54$. Esse fato, no entanto, não havia sido comprovado anteriormente. O que não era esperado e que foi comprovado por este estudo é a redução significativa (46,39\% entre 2010 e 2014) que esse custo tem sofrido, embora tenha apresentado um aumento (18,97\%) em 2015.

No entanto, o dado mais surpreendente é que o custo total com as ações judiciais tem representatividade muito baixa em relação às despesas do setor de saúde, e menor ainda quando são comparados com a receita do Estado (apenas 1,17\% e 0, 15\%, respectivamente). Também surpreende o fato de o custo per capita médio desse fenômeno ser de apenas $R \$ 5,34$ - o maior foi de $R \$ 7,31$ em 2010, e o menor foi de $R \$ 3,73$ em 2014. Esses dados vão na contramão daqueles disponibilizados sobre a judicialização da saúde e, portanto, também não eram esperados.

Vale ressaltar que esses valores se referem, tão somente, às despesas efetuadas com a aquisição de bens e serviços de saúde, excluídos os valores relativos às despesas com o procedimento de compra e entrega de medicamentos (tais como publicação em Diário Oficial, pagamento de transportadora para entrega da medicação e, em alguns casos, custos com a importação) e aqueles referentes ao processo judicial (por exemplo, pagamento dos

\footnotetext{
52 ADVOCACIA-GERAL DA UNIÃO. Ministério da Saúde. Intervenção Judicial na saúde pública: panorama no âmbito da Justiça Federal e apontamentos na seara das justiças estaduais. Brasília, 2012.

53 HACHEM, Daniel Wunder. A noção constitucional de desenvolvimento para além do viés econômico: reflexos sobre algumas tendências do Direito Público brasileiro. A\&C - Revista de Direito Administrativo \& Constitucional, Belo Horizonte, ano 13, n. 53, p. 133-168, jul./set. 2013.

${ }^{54}$ WANG, Daniel Wei L. et al. Os impactos da judicialização da saúde no município de São Paulo: gasto público e organização federativa. Rev. Adm. Pública. Vol. 48, n. 5, p. 1191-1206, set/out. 2014.
} 
HECKTHEUER, Pedro Abib; CASTRO, Raimundo Viana de; HECKTHEUER, Fabio Rychecki. Os impactos da judicialização da saúde no estado de Rondônia no período de 2010 a 2015 e a previsão de gastos para o biênio 2016-2017. Revista Eletrônica Direito e Política, Programa de Pós-Graduação Stricto Sensu em Ciência Jurídica da UNIVALI, Itajaí, v.13, n.2, $2^{\circ}$ quadrimestre de 2018. Disponível em: www.univali.br/direitoepolitica - ISSN 1980-7791

serventuários da justiça, promotores, procuradores e juízes), o que certamente aumentaria a representatividade desses gastos em relação às despesas do setor de saúde e à receita estadual.

O lado obscuro dos gastos com a judicialização da saúde foi demonstrado com a análise dos sequestros judiciais efetuados nas contas do Estado, pois até o ano de 2015 os valores retirados das contas estaduais não eram integrados ao orçamento da Secretaria de Saúde, de modo que até aquele ano não há registro desses valores na Secretaria. A partir de 2016, no entanto, por iniciativa da Gerência de Contas do Tesouro - SEFIN -, ao final de cada mês é montado um processo administrativo contendo todos os sequestros realizados naquele período e enviado ao Núcleo de Mandados Judiciais, para que se proceda à respectiva regularização orçamentária.

Ainda referente aos sequestros judiciais, observa-se que $73,19 \%$ daqueles realizados nas contas do Estado entre 2010 e 2015 foram para o cumprimento de medidas judiciais referentes ao direito à saúde, tendo sido encontrado na pesquisa, ainda que não fora objetivo da pesquisa, que $6,39 \%$ dos casos destinaram-se a garantir o custeio de Tratamento Fora do Domicílio ou de medicamentos ou procedimentos oncológicos, de responsabilidade da União, distorcendo, assim, a distribuição de competência do SUS. Esse fato, em tese, ensejaria a propositura de ação de regresso em face da União, fato que careceria de estudo mais aprofundados e específicos para maior esclarecimento sobre essa realidade.

Os dados, portanto, apontam para os seguintes impactos da judicialização: a criação de um tratamento anti-isonômico de acesso ao SUS, favorecendo excessivamente aqueles que acionam o Judiciário; a existência de uma pequena, mas significante distorção de competência do SUS, sobrecarregando o Estado, nos casos de Tratamento Fora do Domicílio e tratamentos e medicamentos relacionados à oncologia; e a dificuldade de planejar e gerir o orçamento público, tendo em vista a imprevisibilidade da despesa imposta pelas ações judiciais. Essa comprovação é coerente com o resultado de outros trabalhos que estudaram a judicialização da saúde ${ }^{55,56}$.

Para atenuar o impacto provocado pela imprevisibilidade dos gastos imposta pela judicialização da saúde, no presente trabalho foi elaborado um modelo matemático probabilístico, através da análise de regressão linear múltipla, cuja maior aplicação consiste

${ }^{55}$ WANG, Daniel Wei L. et al. Os impactos da judicialização da saúde no município de São Paulo: gasto público e organização federativa. Rev. Adm. Pública. Vol. 48, n. 5, p. 1191-1206, set/out. 2014.

${ }^{56}$ SCAFF, Fernando Facury. Sentenças aditivas, direitos sociais e reserva do possível. In: SARLET, Ingo Wolfgang; TIM, Luciano Benetti. Direitos Fundamentais: orçamento e reserva do possível. Porto Alegre: Livraria do Advogado, 2013. 
HECKTHEUER, Pedro Abib; CASTRO, Raimundo Viana de; HECKTHEUER, Fabio Rychecki. Os impactos da judicialização da saúde no estado de Rondônia no período de 2010 a 2015 e a previsão de gastos para o biênio 2016-2017. Revista Eletrônica Direito e Política, Programa de Pós-Graduação Stricto Sensu em Ciência Jurídica da UNIVALI, Itajaí, v.13, n.2, $2^{\circ}$ quadrimestre de 2018. Disponível em: www.univali.br/direitoepolitica - ISSN 1980-7791

na realização de previsão desses gastos, em 2016 e 2017, de modo que foi possível antever, para esses anos, valores que giram em torno de $\mathrm{R} \$ 6.693 .348,75$ e $\mathrm{R} \$ 6.089 .103,48$, respectivamente, com intervalo de confiança de $95 \%$, aí já incluídos os sequestros judiciais. Salientando-se que com uma futura pesquisa dos dados de 2016 e 2017, se poderá aferir a confiabilidade do modelo probabilístico elaborado.

A partir daí, sabendo antecipadamente o valor anual aproximado que terá que disponibilizar para essa finalidade, caberá ao gestor de saúde pública estadual a decisão quanto ao valor a ser orçado inicialmente, de modo que se possa controlar o incremento a ser realizado no decorrer do ano. Para ter um incremento mínimo, deverá ser orçado um valor inicial máximo, e vice-versa.

Os dados obtidos junto à Gerência de Contas do Tesouro estadual dão conta de que até o mês de outubro de 2016, o Estado já havia gasto $R \$ 4.743 .797,53$ em 874 sequestros judiciais. Como o valor inicialmente previsto no orçamento para 2016 foi de $R \$$ 2.000.000,00, o custo da judicialização, nesse ano, já se aproxima de $R \$ 7.000 .000,00$, mas ainda dentro do intervalo de confiança estimado pelo modelo de previsão.

Lamentavelmente, não foi possível verificar quantas pessoas foram beneficiadas com a judicialização da saúde, no período analisado, de modo que se pudesse estabelecer uma estimativa de qual é o percentual da população que está tendo acesso a essa fatia do orçamento da saúde no Estado. Futuros trabalhos certamente serão relevantes para completar o quadro que esse artigo começou a traçar e ampliar o conhecimento sobre esse fenômeno em Rondônia.

\section{REFERÊNCIA DAS FONTES CITADAS}

ADVOCACIA-GERAL DA UNIÃO. Ministério da Saúde. Intervenção Judicial na saúde pública: panorama no âmbito da Justiça Federal e apontamentos na seara das justiças estaduais. Brasília, 2012.

BARCELLOS, Ana Paula de. A eficácia jurídica dos princípios constitucionais. Rio de Janeiro: Renovar, 2002.

BARROSO, Luís Roberto. Curso de Direito Constitucional Contemporâneo: os conceitos fundamentais e a construção do novo modelo. 5. ed. São Paulo: Saraiva, 2015.

BOBBITT, Philip; CALABRESI, Guido. Tragic Choices - The conflicts society confronts in the allocation of tragically scarce resources. New Yorque: WW. Norton \& Company, 1978.

BRASIL. Conselho Nacional de Justiça. Resolução no 61 de 2008. Disciplina o procedimento de cadastramento de conta única para efeito de constrição de valores em dinheiro por intermédio do Convênio BACENJUD e dá outras providências. DJ-e nº 68/2008, Brasília, DF, 15.10.2008, p. 2-4. 
HECKTHEUER, Pedro Abib; CASTRO, Raimundo Viana de; HECKTHEUER, Fabio Rychecki. Os impactos da judicialização da saúde no estado de Rondônia no período de 2010 a 2015 e a previsão de gastos para o biênio 2016-2017. Revista Eletrônica Direito e Política, Programa de Pós-Graduação Stricto Sensu em Ciência Jurídica da UNIVALI, Itajaí, v.13, n.2, $2^{\circ}$ quadrimestre de 2018. Disponível em: www.univali.br/direitoepolitica - ISSN 1980-7791

BRASIL. Constituição da República Federativa do Brasil. Promulgada em 5 de outubro de 1988.

BRASIL. Emenda constitucional no 29 de 2000. Altera os arts. 34, 35, 156, 160, 167 e 198 da Constituição Federal e acrescenta artigo ao Ato das Disposições Constitucionais Transitórias, para assegurar os recursos mínimos para o financiamento das ações e serviços públicos de saúde. Brasília, 13.09.2000.

BRASIL. Superior Tribunal de Justiça. Recurso Ordinário em Mandado de Segurança no 24.197, do Tribunal de Justiça do, Brasília, DF, 4 de maio de 2010. Disponível em: http://stj.jusbrasil.com.br/jurisprudencia/16825941/recurso-ordinario-em-mandado-deseguranca-rms-24197-pr-2007-0112500-5/inteiro-teor-16825942. Acesso em: 28 out. 2015.

BRASIL. Supremo tribunal Federal. ADPF no 45. Rel. Min. Celso de Mello, julgado em 29.04.2004. DJ, 04.052004.

BRASIL. Supremo Tribunal Federal. Medida Cautelar na Petição n. 1246, Presidente Ministro Sepúlveda Pertence, decisão Proferida pelo Ministro Celso de Mello, julgado em 31.01.1997. DJ, 13.02. 1997.

BRASIL. Supremo Tribunal Federal. STA: 175 CE. Relator: Min. Gilmar Mendes, julgado em 16.06.2009. DJe, 25.06.2009.

CALIENDO, Paulo. Reserva do possível, direitos fundamentais e tributação. In: SARLET, Ingo Wolfgang; TIM, Luciano Benetti. Direitos Fundamentais: orçamento e reserva do possível. Porto Alegre: Livraria do Advogado, 2013.

FERNANDES, Bernardo Gonçalves. Curso de Direito Constitucional. 7. ed. São Paulo: Juspodivm, 2015.

FERRAJOLI, Luigi. Los Fundamentos de los Derechos Fundamentales. Madrid: Trotta, 2001.

GLOECKNER, Joseane Ledebrum. A reserva do possível como limite à efetividade do direito fundamental à saúde. A\&C-Revista de Direito Administrativo \& Constitucional, v. 13, n. 51, p. 233-250, 2013.

HACHEM, Daniel Wunder. A noção constitucional de desenvolvimento para além do viés econômico: reflexos sobre algumas tendências do Direito Público brasileiro. A\&C - Revista de Direito Administrativo \& Constitucional, Belo Horizonte, ano 13, n. 53, p. 133168, jul./set. 2013.

INTERFARMA. Associação da Indústria Farmacêutica de Pesquisa. Judicialização da saúde na prática: fatos e dados da realidade brasileira. São Paulo, 2016. Disponível em: <http://www.interfarma.org.br/uploads/biblioteca/102-caderno-judicializacao-jul2016-

site.pdf >. Acesso em: 08.082016.

MENDES, Gilmar Ferreira; BRANCO, Paulo Gustavo Gonet. Curso de Direito Constitucional. 7. ed., ver. e amp. São Paulo: Saraiva, 2012.

MONTGOMERY, Douglas C.; RUGER, George Ruger. Estatística Aplicada e Probabilidade para Engenheiros. 2. ed. Rio de Janeiro: LTC, 2008.

NETO, Claudio Pereira de Souza; SARMENTO, Daniel. Direito Constitucional: Teoria, História e Métodos de Trabalho. 2a Ed. São Paulo: Saraiva, 2014

PEPE et al. A judicialização da saúde e os novos desafios da gestão da assistência farmacêutica. Ciência \& Saúde Coletiva. Rio de Janeiro, v. 15, n. 5, p. 2.405-2.414, 2010. 
HECKTHEUER, Pedro Abib; CASTRO, Raimundo Viana de; HECKTHEUER, Fabio Rychecki. Os impactos da judicialização da saúde no estado de Rondônia no período de 2010 a 2015 e a previsão de gastos para o biênio 2016-2017. Revista Eletrônica Direito e Política, Programa de Pós-Graduação Stricto Sensu em Ciência Jurídica da UNIVALI, Itajaí, v.13, n.2, $2^{\circ}$ quadrimestre de 2018. Disponível em: www.univali.br/direitoepolitica - ISSN 1980-7791

RONDÔNIA. Tribunal de Justiça do Estado de Rondônia. 1a Vara Cível de Cacoal. Ação Ordinária 0006109-69.2013.8.22.0007. Juíza de Direito Emy Karla Yamamoto Roque, julgado em 29.08.2014. DJ, 03.09.2014.

RONDÔNIA. Tribunal de Justiça do Estado de Rondônia. AGV 00213558920148220001 RO 0021355-89.2014.822.0001, Rel. Des. Renato Mimessi, julgado em 04.10.2016. DOE, 07.10 .2016$.

RONDÔNIA. Tribunal de Justiça do Estado de Rondônia. APL 00106627520128220014 RO 0010662-75.2012.822.0014. Rel. Des. Roosevelt Queiroz Costa, 2a Câmara Especial, julgado em 13.05.2014. DOE, 28.05.2014.

SARLET, Ingo Wolfgang; FIGUEIREDO, Mariana Filchtiner. Reserva do possível, mínimo existencial e direito à saúde: algumas aproximações. In: SARLET, Ingo Wolfgang; TIM, Luciano Benetti. Direitos Fundamentais: orçamento e reserva do possível. Porto Alegre: Livraria do Advogado, 2013.

SARLET, Ingo Wolfgang; MARINONI, Luiz Guilherme; MITIDIERO, Daniel. Curso de Direito Constitucional. 6. ed., amp. São Paulo: Saraiva, 2017.

SCAFF, Fernando Facury. Direito à saúde e os Tribunais. In: NUNES, Antônio José Avelãs; SCAFF, Fernando Facury. Os Tribunais e o Direito à Saúde. Porto Alegre: Livraria do Advogado, 2011.

SCAFF, Fernando Facury. Sentenças aditivas, direitos sociais e reserva do possível. In: SARLET, Ingo Wolfgang; TIM, Luciano Benetti. Direitos Fundamentais: orçamento e reserva do possível. Porto Alegre: Livraria do Advogado, 2013.

VIANNA, Luiz Werneck et al. Dezessete anos de judicialização da política. Tempo Social, revista de sociologia da USP. Vol. 19, n 2, p. 39-85, nov. 2007.

WANG, Daniel Wei Liang. Escassez de recursos, custos dos direitos e reserva do possível na jurisprudência do STF. In: SARLET, Ingo Wolfgang; TIMM, Luciano Benetti (Coord.). Direitos fundamentais: orçamento e "reserva do possível". 2. ed. Porto Alegre: Livraria do Advogado, 2010.

WANG, Daniel Wei Liang. et al. Os impactos da judicialização da saúde no município de São Paulo: gasto público e organização federativa. Rev. Adm. Pública. Vol. 48, n. 5, p. 11911206, set/out. 2014.

Recebido em: 04/06/2018

Aprovado em: 12/06/2018 